Exon, N.F., Kennett, J.P., and Malone, M.J. (Eds.)

Proceedings of the Ocean Drilling Program, Scientific Results Volume 189

\title{
2. LATE EOCENE-QUATERnARY DinOfLAgellate CySTS FROM ODP SITE 1168, OFF WESTERN TASMANIA 1
}

\author{
H. Brinkhuis, ${ }^{2}$ D.K. Munsterman, ${ }^{3}$ S. Sengers, ${ }^{2}$ A. Sluijs, ${ }^{2}$ \\ J. Warnaar, ${ }^{2}$ and G.L. Williams ${ }^{4}$
}

\begin{abstract}
Palynomorphs were studied in samples from Ocean Drilling Program (ODP) Leg 189, Hole 1168A (slope of the western margin of Tasmania; $2463 \mathrm{~m}$ water depth). Besides organic-walled dinoflagellate cysts (dinocysts), broad categories of other palynomorphs were quantified in terms of relative abundance. In this contribution, we provide an overview of the early late Eocene-Quaternary dinocyst distribution and illustrate main trends in palynomorph distribution.

Dinocyst species throughout Hole 1168A are largely cosmopolitan with important contributions of typical low-latitude taxa and virtual absence of endemic Antarctic taxa. Dinocyst stratigraphic distribution broadly matches that known from the Northern Hemisphere and equatorial regions, although significant differences are noted. Selected potentially biochronostratigraphically useful events are summarized. The distribution of dinocysts in the middle-upper Miocene interval is rather patchy, probably due to prolonged exposure to oxygen. An important general aspect in the dinocyst assemblages is the near absence of Antarctic endemic species and the apparent influence of relatively warm waters throughout the succession at Site 1168. General palynomorph distribution indicates continued deepening from an initial shallow, even restricted, marine setting from late Eocene-Quaternary times. A curious massive influx of small skolochorate acritarchs is recorded throughout the late early-early middle Miocene; the significance of this
\end{abstract}

${ }^{1}$ Brinkhuis, H., Munsterman, D.K., Sengers, S., Sluijs, A., Warnaar, J., and Williams, G.L., 2003. Late EoceneQuaternary dinoflagellate cysts from ODP Site 1168, off western Tasmania. In Exon, N.F., Kennett, J.P., and Malone, M.J. (Eds.), Proc. ODP, Sci. Results, 189, 1-36 [Online]. Available from World Wide Web: <http:// www-odp.tamu.edu/publications/ 189_SR/VOLUME/CHAPTERS/ 105.PDF>. [Cited YYYY-MM-DD] ${ }^{2}$ Laboratory of Palaeobotany and Palynology, Utrecht University, Budapestlaan 4, 3584CD Utrecht, The Netherlands. Correspondence author: h.brinkhuis@bio.uu.nl

${ }^{3}$ The Netherlands Institute of Applied Geosciences (NITG)-TNO, National Geological Survey, PO Box 80015, 3508 TA Utrecht, The Netherlands.

${ }^{4}$ Geological Survey of Canada (Atlantic), Bedford Institute of Oceanography, PO Box 1006, Dartmouth NS B2Y 4A2, Canada.

Initial receipt: 12 November 2002 Acceptance: 15 July 2003

Web publication: 28 October 2003

Ms 189SR-105 
signal is not yet understood. A general long-term oligotrophic nature of the surface waters influencing Site 1168 is suggested from the low abundance of (proto) peridinioid, presumably heterotrophic, species.

The overall dinocyst distribution pattern corresponds to the longterm existence of a Leeuwin-like current influencing the region, including Site 1168, confirming results of earlier studies on other microfossil groups. The occasional influence of colder surface water conditions is, however, also apparent, notably during the late Pliocene-Quaternary, indicating the potential of high-resolution dinocyst analysis for future paleoceanographic studies.

\section{INTRODUCTION}

Ocean Drilling Program (ODP) Site 1168 is located in middle bathyal water depths $(2463 \mathrm{~m})$ on the slope of the western margin of Tasmania (Fig. F1). Hole 1168A penetrated marine rift to open-margin sediments deposited from the early late Eocene onward as Australia moved northward from Antarctica (Shipboard Scientific Party, 2001ab). Initially, in the Eocene, the site was at the far eastern end of the restricted AustraloAntarctic Gulf and separated from the Pacific Ocean by the Tasmanian Promontory-South Tasman Rise. Plate movements and related margin subsidence led to its Neogene location in open water facing a broad Southern Ocean to the west.

Microfossils belonging to seven major groups were recovered from the sedimentary succession at Site 1168 . The combined shipboard results indicate that the upper Eocene-Quaternary succession is essentially complete. Of the siliceous groups, diatoms are generally rare and sporadic, whereas radiolarians are generally rare but occasionally abundant. Calcareous microfossils (foraminifers and nannofossils) are generally abundant down to the basal Oligocene. Benthic foraminifers are present throughout the entire sequence, with the upper Eocene showing low abundances and diversity of mainly agglutinating species. Onboard studies also indicated the presence and local abundance of organic-walled dinoflagellate cysts (dinocysts) in the succession of Hole 1168 A. Dinocysts are rare in the middle Miocene, whereas sporomorphs are reported to dominate the palynomorph assemblages in samples from the lower part of Hole 1168A assigned to the late Eocene (Shipboard Scientific Party, 2001b). Rather unique to this site, compared to other ODP Leg 189 sites or other locations in the Southern Ocean, is the reasonably consistent occurrence of dinocysts throughout the Oligocene and Neogene deposits (Shipboard Scientific Party, 2001a).

So far about two to three samples per core (average spacing $=\sim 4 \mathrm{~m}$ ) from Hole $1168 \mathrm{~A}$ were subjected to palynological analysis. Besides dinocysts, broad categories of other palynomorphs were quantified. Here, we aim to provide an overview of the dinocyst distribution from the upper Eocene-Quaternary interval and to illustrate main trends in palynomorph distribution. Several new dinocyst taxa have been recorded; some of them are informally characterized herein, others are placed in broad generic groups. Future work on this material will describe these taxa formally and more details on other constituents of applied generic groupings will be presented therein. Because only very few previous dinocyst studies are available, for age assessment of first occurrences (FO) and last occurrences (LO) of taxa, we principally rely on the age model provided for Site 1168 constructed by other means (Stickley et al., this volume). Comparison of ranges may only be performed on the basis of
F1. Leg 189 drilling locations, p. 19.

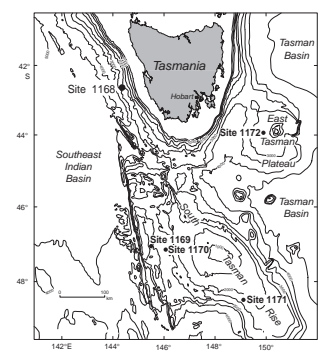


Northern Hemisphere records and are herein only discussed for a few species, where appropriate.

\section{MATERIAL AND METHODS}

The combined cored sequence at Site 1168 (see Figs. F1, F2) (mainly Hole 1168A; total depth $[\mathrm{TD}]=883.5$ meters below seafloor [mbsf]) broadly consists of $260 \mathrm{~m}$ of nannofossil ooze of middle Miocene and younger age (lithostratigraphic Unit I); $400 \mathrm{~m}$ of clayey chalk, nannofossil siltstone, and sandstone of early Miocene and Oligocene age (Unit II); and $220 \mathrm{~m}$ of shallow-marine carbonaceous mudstone and sandstone (Units III-V) of late Eocene age (Shipboard Scientific Party, 2001b). Construction of a composite section of the triple-cored portion of the sedimentary sequence $(\sim 110 \mathrm{mbsf})$ indicates that there are no stratigraphic gaps to that depth. Beyond that, there are limited gaps, but overall core recovery averaged 93\%. More details on lithology and sedimentology are available in the Leg 189 Initial Reports volume (Shipboard Scientific Party, 2001b).

Initial shipboard data and interpretation suggests that sedimentation rates were relatively low throughout the late Eocene-Quaternary for a setting close to land $(6.9-1.5 \mathrm{~cm} / \mathrm{k} . \mathrm{y}$.$) . The succession of sediment, cli-$ matic, and biotic changes recorded at Site 1168 was interpreted to reflect the three major steps in Cenozoic climate state, namely, "Greenhouse" in the late Eocene, "Doubthouse" of intermediate mode in the Oligocene-early Miocene, and "Icehouse" since the middle Miocene (Shipboard Scientific Party, 2001a). Relatively rapid changes mark the boundaries at the Eocene-Oligocene transition and during the middle Miocene at $\sim 14 \mathrm{Ma}$. The most conspicuous change in the sediment and biotic sequence occurred during the transition from the latest Eocene to the early Oligocene, with an apparent reduction in sedimentation rates, deposition of glauconite sands, and a possible hiatus in the earliest Oligocene (Stickley et al., this volume). This transition is seen to reflect a transient event associated with temporarily increased bottom water activity in the basin (Shipboard Scientific Party, 2001a). The timing of this episode is apparently consistent with the hypothesis linking the critical deepening of the Tasmanian Gateway to major cooling of Antarctica and associated cryospheric development (see also Stickley et al., submitted [N1]). However, these links are as yet poorly understood (see discussion in Huber et al., submitted [N2]). For further information on the general geologic and oceanographic setting of Site 1168, see reviews in Shipboard Scientific Party (2001a, 2001b).

\section{Palynological Processing and Counting}

Organic-walled microfossils were extracted for analysis using standard palynological processing techniques at the Laboratory of Palaeobotany and Palynology at Utrecht University. From the core samples, $\sim 5 \mathrm{~cm}^{3}$ of wet sediment was oven-dried at $60^{\circ} \mathrm{C}$ and weighed $(8-14 \mathrm{~g})$. Processing involved an initial treatment in hydrochloric acid (10\%) to dissolve carbonates, followed by a treatment of hydrofluoric acid (38\%) to dissolve silicates. After each acid step, samples were washed two times by decanting after $24 \mathrm{hr}$ settling and filling up with distilled water. The hydrofluoric step included $2 \mathrm{hr}$ shaking at $\sim 250 \mathrm{rpm}$ and adding 30\% hydrochloric acid to remove fluoride gels. Then, samples were repeatedly washed in distilled water and finally sieved through a $15-\mu \mathrm{m}$
F2. Terrestrial palynomorphs and oceanic dinocysts, p. 20.

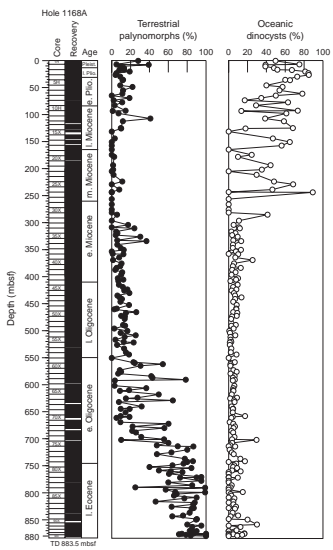


nylon mesh sieve (10 $\mu$ m nylon mesh sieve for Quaternary samples). To break up clumps of residue, the sample was placed in an ultrasonic bath for a maximum of $5 \mathrm{~min}$ after the first sieving. The residue remaining on the sieve was transferred to a glass tube. The tubes were centrifuged for $5 \mathrm{~min}$ at $2000 \mathrm{rpm}$ and the excess amount of water was removed. For slide preparation, residues were transferred to vials and glycerin water was added. The residue was homogenized, no coloring was added, a droplet of each residue was mounted on a slide adding glycerin jelly, and the mixture was stirred and sealed with nail varnish. Two slides per sample were prepared.

Where possible, slides were initially counted to 200 palynomorphs, followed by the counting of 200 or more dinocysts. When dealing with low yields, counting was stopped after two slides at this stage (see Table T1). Dinocysts were counted at species level, whereas other palynomorphs were counted in broad categories, namely, bisaccate pollen, other pollen, spores, inner linings of foraminifers (if $>3$ chambers), remains of prasinophyte or chlorophyte algae such as Cymatiosphaera and Tasmanites spp., remains of Copepod eggs, and acritarchs. Here, of these other palynomorphs, only the calculated terrestrial percentage is presented to provide a general characterization (Table T1; Fig. F2). Aquatic palynomorphs are usually dominated by dinocysts. The lower Miocene interval is, however, characterized by massive influxes of small skolochorate acritarchs (palynomorphs of unknown affinity); this is an exceptional phenomenon. These microfossils occur in up to two orders of magnitude larger concentrations than dinocysts. Samples characterized by such huge influxes of acritarchs are marked in Table T1, but numbers were kept separate from the general palynomorph count as they obscure trends in relative terrestrial palynomorph abundance, for example.

The postcruise studies are here supplemented by the onboard studies performed on core catcher material. Essentially, shipboard processing followed the steps as described above, using a 20- $\mu \mathrm{m}$ stainless steel sieve (leading to the potential loss of small palynomorphs), and equipment was not as sophisticated as common modern laboratory setups. Results from these shipboard samples should be taken as rough estimations.

Cyst taxonomy follows that cited in Williams et al. (1998) and Rochon et al. (1999). A species list, including remarks on new taxa, is presented in the "Appendix," p. 15. For the purpose of the present study, which only provides a broad overview of the dinocyst distribution and general palynological contents, emphasis is placed on potential age-diagnostic taxa. Other species are placed in generic groups (see the "Appendix," p. 15). Future studies will consider dinocyst distribution of rare species, besides other aspects, in more detail. Slides are stored in the collection of the Laboratory of Palaeobotany and Palynology, Utrecht University.

\section{Age Model}

We adopt the postcruise age model as presented in Stickley et al. (this volume) for Hole 1168A. Ages (in mega-annum [Ma]) are indicated in Table T1 where relevant; for more detailed information see Stickley et al. (this volume). As an indication, the Pliocene/Pleistocene boundary occurs at $\sim 16 \mathrm{mbsf}$, the early/late Pliocene boundary at $\sim 46 \mathrm{mbsf}$, the Miocene/Pliocene boundary at $\sim 92 \mathrm{mbsf}$, the middle/late Miocene boundary at $\sim 190 \mathrm{mbsf}$, the early/middle Miocene boundary at 265 mbsf, the Oligocene/Miocene boundary at $\sim 420 \mathrm{mbsf}$, the early/late
T1. Selected palynological results, p. 21. 
Oligocene boundary at $~ 580 \mathrm{mbsf}$, the Eocene/Oligocene boundary (sensu Global Stratotype Section and Point [GSSP]) at $~ 745 \mathrm{mbsf}$, and the middle/late Eocene boundary close to the bottom of the hole $(\sim 880$ mbsf). Using this age model, sedimentation rates varied from $\sim 3.5 \mathrm{~cm} /$ k.y. in the Eocene to $\sim 1.5 \mathrm{~cm} / \mathrm{k} . \mathrm{y}$. during most of the Neogene (Stickley et al., this volume).

\section{RESULTS}

Dinocyst distribution, relative abundance of terrestrial palynomorphs, samples with massive influx of acritarchs, as well as percentages of non-neritic (oceanic) dinocysts (see explanation below) are depicted in Table T1. A summary of selected potentially stratigraphically useful dinocyst events and derived ages is given in Table T2. Plots of percent terrestrial palynomorphs and percent oceanic dinocysts vs. depth and age are given in Figure F2.

\section{Palynology: General}

Recovery of palynomorphs is quite variable. Dinocysts are in most cases the most prominent palynomorphs in the uppermost Eocenelower Miocene and in the Pliocene and Quaternary. Sporomorphs dominate the upper Eocene and are frequent in the overlying palynological associations (Fig. F2), as are the organic linings of foraminifers. Sporadic occurrences of representatives of the chlorophyte Tasmanites, as well as other prasinophytes, have been recorded in some samples (not shown). Massive influxes of small skolochorate acritarchs of unknown affinity (Pl. P1, figs. 140-151) occur between $~ 387$ and 210 mbsf (upper lower-lower middle Miocene). Pulses of up to 1000 acritarchs vs. 1 dinocyst predominantly occur between 385 and 340 mbsf. The dinocyst (and palynological) record becomes patchy in the middle Miocenebasal Pleistocene interval. Probably, the low sedimentation rates and related prolonged exposure to oxic conditions hampered significant accumulation of organic matter, including organic-walled dinocysts.

\section{Dinoflagellate Cysts: General}

Despite many attempts, only few studies of Oligocene-Neogene dinocysts are available from the circum-Antarctic domain; representatives of this fossil group have been found only sporadically (see overviews in Hannah et al., 1998; Wrenn et al., 1998; McMinn et al., 2001; Harland and Pudsey, 2002). This contrasts markedly the situation in the older Paleogene, where many studies have reported rich dinocyst associations around Antarctica (e.g., Goodman and Ford, 1983; Wilson, 1985, 1988; Wrenn and Hart, 1988; Mohr, 1990; Mao and Mohr, 1995; Crouch and Hollis, 1996; Truswell, 1997; Hannah, 1997a, 1997b; Hannah and Raine, 1997, Brinkhuis et al., this volume; Sluijs et al., this volume, for overviews). Only recently a first ever quasi-continuous Southern Ocean Oligocene-early Miocene dinocyst succession was documented from the Ross Sea continental shelf (Cape Roberts Project, see Hannah et al., 2000, and discussion in Brinkhuis et al., this volume). In effect, McMinn (1995) noted the absence of Neogene dinocysts and postulated that the loss of shelves (due to glaciation) from the Antarctic continent from the basal Oligocene onward contributed to this local extinction of the cyst-producing dinoflagellates. Rather, as also suggested by Wrenn
T2. Selected potentially age-indicative dinocyst events, p. 22.

P1. Illustrations of taxa, p. 23.

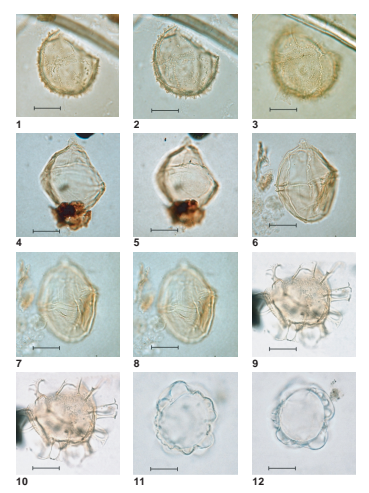


et al. (1998), the organic wall of the dinocysts is not resistant to the oxygen-rich waters in the Antarctic domain and/or winnowing at depth and/or low sedimentation rates precludes preservation of these microfossils (e.g., Zonneveld et al., 1997, 2001; Versteegh and Zonneveld, 2002; Hopkins and McCarthy, 2002). Southern Ocean dinocyst assemblages should be present when preservation requirements are met. The studies by, for example, Hannah et al. (2000) on the Ross shelf or McMinn et al. (2001) analyzing Pliocene dinocysts and diatoms from Deep Sea Drilling Project (DSDP) Site 594, Chatham Rise, illustrate this aspect. Moreover, McMinn and Wells (1997) already demonstrated the potential of dinocyst analysis for paleoenvironmental reconstructions in the Quaternary in the region using piston-cored materials from locations close to Site 1168. The relative abundance of dinocysts in the Oligocene-Neogene of Site 1168 may therefore be taken to indicate that water mass, bottom conditions, and sedimentation rates were suitable for preservation of organic material.

Dinocyst species throughout Hole 1168A are largely cosmopolitan and rather long ranging, with important contributions of typical lowlatitude taxa. Dinocyst stratigraphic distribution broadly matches that known from the Northern Hemisphere and equatorial regions, although significant differences are noted (see below). Selected potentially biochronostratigraphically useful events are summarized in Table T2. Unfortunately, the distribution of dinocysts in the middle-upper Miocene is rather patchy due to reasons discussed above. This hampers detailed cross-hemisphere comparisons. For example, the ranges of species stratigraphically important in Northern Hemisphere Neogene deposits such as Achomosphaera andalousiensis, Cerebrocysta poulsenii, Edwardsiella sexispinosum, and Labyrinthodinium truncatum, broadly match those recorded here, but not in detail, probably due to poor preservation/oxidation. The Eocene-Oligocene to perhaps lower Miocene interval has more potential for detailed comparisons (see below). Consistent with earlier studies based on other microfossil groups suggesting that a relatively warm current akin to the Leeuwin Current (or "protoLeeuwin Current") dominated this region for the last $\sim 40$ m.y. (e.g., Li et al., 2003; Huber et al., submitted [N2]), the suite of events recorded in Hole 1168A has much in common with those known from southern European (Tethyan) successions (like those reported by, e.g., Biffi and Manum, 1988; Brinkhuis et al., 1992; Brinkhuis and Biffi, 1993; Wilpshaar et al., 1996). Conspicuously, species belonging to the "Transantarctic Flora" (cf. Wrenn and Beckmann, 1982) are virtually absent. Only very few specimens of species belonging to this endemic flora are recorded at Site 1168 (e.g., Deflandrea antarctica, Octodinium askiniae, and Enneadocysta partridgei). Several yet undescribed species were recorded (e.g., new species of Cerebrocysta, Hystrichokolpoma, Eocladopyxis, and Cannosphaeropsis). They will be treated in more detail elsewhere.

\section{Latest Middle-Late Eocene}

Although the latest middle-late Eocene dinocyst record of Hole $1168 \mathrm{~A}$ is somewhat patchy, probably due to the extremely shallow marine setting, the species composition broadly matches that described from the southeastern Australian surface section at the Browns Creek locality (Cookson and Eisenack, 1965; Stover, 1975). Ranges of, for example, Schematophora speciosa, Aireiana verrucosa, Hemiplacophora semilunifera, and Stoveracysta ornata appear useful for regional and even broad global correlation. Many of the Browns Creek late Eocene di- 
nocysts have been recorded from locations around the world, but notably in central and northern Italy, including the Priabonian-type section (Brinkhuis and Biffi, 1993; Brinkhuis, 1994). It appears that these index species have slightly earlier range tops in this region than in the Tethys. This may be related to the progressive cooling during the late Eocene and/or the warm-temperate nature of the surface waters (see discussion below). The dinocyst distribution across the Eocene/Oligocene boundary, also from other Leg 189 sites, is discussed in more detail in Sluijs et al. (this volume).

It is likely that older Paleogene and Cretaceous deposits underlie the upper Eocene at Site 1168, not recovered during Leg 189 drilling. Studies of the nearby borehole at Cape Sorell indicate the presence of at least $2400 \mathrm{~m}$ of Campanian/Maastrichtian-middle Eocene sediments in the immediate surroundings of Site 1168 (Boreham et al., 2002). Palynological studies (MacPhail in Boreham et al., 2002) indicate that the signature of these deposits is very similar to those recovered at Site 1168 , with endemic species being relatively rare. This contrasts with results from dredge samples taken slightly farther to the south, along the South Tasman Rise (Truswell, 1997). Samples assigned to the middle Eocene there are characterized by the distinct presence of the Transantarctic Flora (Truswell, 1997). It is therefore apparent that completely different surface waters influenced sites more to the south from Site 1168 and Cape Sorell. Onboard results from Sites 1170 and 1171, also showing high abundances of the Transantarctic Flora in the Eocene, on the South Tasman Rise confirm this aspect (Shipboard Scientific Party, 2001c, 2001d; Brinkhuis et al.; Sluijs et al., both this volume).

\section{Oligocene}

Relatively poorly diversified assemblages characterize the Oligocene succession at Site 1168 with long-ranging cosmopolitan representatives of Spiniferites, Operculodinium, Hystrichokolpoma, and Cleistosphaeridium being common to frequent. Thalassiphora pelagica and Apteodinium australiense may be abundant in certain intervals. The near absence of Deflandrea spp. or of any (proto) peridinioid (probably heterotrophic) dinocysts is remarkable. Yet, other dinocysts are present in the background, albeit with a scattered distribution. The succession of events in this background pattern in the Oligocene interval shows remarkable resemblance to the succession of central Italy as summarized in Wilpshaar et al. (1996). Tethyan index species such as Areoligera? semicirculata, Wetzeliella gochtii, Hystrichokolpoma sp. cf. Homotryblium oceanicum, Hystrichokolpoma pusilla, Chiropteridium spp., Distatodinium biffii, and Ectosphaeropsis burdigalensis have virtually the same stratigraphic succession here as they display in Italy. They do, unfortunately, have a rather patchy distribution pattern at Site 1168, whereas they occur more consistently in Italy. For example, the FO of D. biffii matches its reported FO in Italy, following the current age model; its LO, however, occurs earlier at Site 1168. This may be due to the scarcity of this index fossil and the current rather large sample spacing. The scattered occurrences of Hystrichokolpoma sp. cf. H. oceanicum, H. pusilla, and Chiropteridium spp. basically fall within their ranges in Italy, but the pattern at Site 1168 is inconsistent so far. The FO of E. burdigalensis, an index event for recognition of the Oligocene/Miocene $(\mathrm{O} / \mathrm{M})$ boundary in Italy (Brinkhuis et al., 1992), apparently occurs much earlier at Site 1168, if the current age model is accepted. It thus appears that this species migrated from Southern Hemisphere locations to the Northern Hemi- 
sphere at or about $\mathrm{O} / \mathrm{M}$ times. However, a recent study of Chattian deposits in Belgium reports the FO of E. burdigalensis to occur well below the $\mathrm{O} / \mathrm{M}$ boundary as well (van Simaeys et al., in press). Combined evidence therefore suggests this form to be a temperate to warm-temperate species. The FO of E. burdigalensis is followed upsequence by the successive FOs of Membranilarnacia? picena and a form morphologically similar to Stoveracysta conerae (Stoveracysta cf. conerae) at Site 1168. This pattern is identical to the Italian lower Miocene succession, but this suite of events appears (much) earlier at Site 1168. Remarkably, the FO of $D$. biffii practically coincides with a single influx of Svalbardella spp. This conjunction of events mimics the situation in central Italy (Wilpshaar et al., 1996) and can even be traced to near the Rupelian/Chattian boundary in their type region (Van Simaeys et al., in press). In Italy, most recent information places these events at the base of Chron C9n (Prof. R. Coccioni, University of Urbino, pers. comm., 2003). The integrated magnetobiostratigraphic age model for Hole 1168A also indicates these events to be associated with the base of Chron C9n. Although international debate on the GSSP of the Rupelian/Chattian is ongoing, indications are that this episode will be selected to represent this important boundary in geological history. The aforementioned dinocyst events apparently have a widespread nature and may well be associated with a pronounced episode of global cooling (possibly oxygen isotope [Oi] event Oi2b; e.g., Miller et al., 1998) that affected surface waters and circulation worldwide. The $\mathrm{O} / \mathrm{M}$ transition around $\sim 410$ mbsf is characterized by a marked influx of $A$. australiense and a new species of Eocladopyxis (Table T1).

\section{Miocene}

The distribution of dinocysts in the middle-upper Miocene is rather patchy due to reasons discussed above. The lower Miocene, however, has reasonable recovery and basically shows the same basic pattern as the Oligocene: relatively poorly diversified assemblages, with longranging cosmopolitan representatives of Spiniferites and Operculodinium being common to frequent. Cerebrocysta spp. and Reticulatosphaera actinocoronata may be abundant in certain intervals. Typical oceanic (nonneritic) taxa such as Nematosphaeropsis and Impagidinium spp. markedly increase in abundance from the lower Miocene onward (Fig. F2). Pentadinium laticinctum has an acme near the top of the lower Miocene. Typical background taxa are Invertocysta spp. and E. sexispinosum. In the younger Miocene, where samples yield reasonably preserved dinocysts again, these trends continue, while potential index taxa, also relevant for cross-hemisphere comparison, such as A. andalousiensis, C. poulsenii, Mendicodinium sp. A of Wrenn and Kokinos, 1986, and L. truncatum are sporadically present. Several taxa have apparent range tops in the middle and upper Miocene interval but, again, the patchy record precludes any conclusions at this stage. As for the Oligocene, the near absence of (proto) peridinioid dinocysts is noteworthy. This group may reach high abundances in Neogene sequences around the world and is important for stratigraphic and environmental considerations (also discussed below). The virtual absence of cysts of Protoperidinium spp. may be related to poor preservation of organic materials in general or to the prevalence of oligotrophic water masses.

As noted above, notably the lower Miocene interval is marked by massive influxes of small skolochorate acritarchs. High magnification studies using scanning electron microscopy (SEM) (see Pl. P1, figs. 140- 
151) show that some of these appear to have angular openings similar to archaeopyles of dinoflagellate cysts. Although they probably represent a cyst stage of an unknown group of algae, further interpretation of this signal is not possible at this stage.

\section{Pliocene-Quaternary}

The Pliocene-Quaternary record is more consistent than the underlying Miocene interval, possibly due to changing oceanographic and depositional settings and/or sedimentation rates. Trends already apparent in the Miocene continued during the Pliocene to Quaternary (viz., everincreasing abundances of typical oceanic species such as Nematosphaeropsis and Impagidinium spp.). The Pliocene interval is primarily marked by an influx of Operculodinium echigoense sensu McMinn (1992, 1993). This author recorded optima of this species at Sites 815 and 817 (Northeastern Australian margin) in the Pliocene and Pleistocene. This apparently tropical species has its optimum between 95 and $65 \mathrm{mbsf}$ in Hole 1168A. Protoperidinioid species such as Brigantedinium spp. and Algidasphaeridum spp. begin to appear more consistently in the younger Pliocene. This and the overlying youngest interval of Hole 1168A are characterized by fluctuating abundances of the warm-water species Impagidinium aculeatum, Impagidinium paradoxum, Impagidinium patulum, and cosmopolitan Nematosphaeropsis spp. (cf. Rochon et al., 1999). Occasionally, the cold-water species Impagidinium pallidum is present as well. Similar assemblages were recovered from nearby sites (McMinn and Wells, 1997), although these authors did not report the presence of, for example, Algidasphaeridium spp. or Pentapharsodinium dalei.

\section{PALEOENVIRONMENTAL CONSIDERATIONS}

In this paper, we are principally concerned with providing overall trends emerging from the initial data set. For this purpose, trends in the relative abundance of terrestrial palynomorphs and oceanic (non-neritic) dinocysts are depicted in Figure F2. Species marked with (o) in Table $\mathrm{T} 1 \mathrm{~h}$ have been used to generate this curve, making use of previous studies focusing on global modern dinocyst distribution and empirical paleoenvironmental evidence from a wide variety of sources (e.g., Brinkhuis and Biffi, 1993; Brinkhuis, 1994; Stover et al., 1996).

The succession at Site 1168 was interpreted to reflect an initial shallow-water, nearshore, restricted marine setting with poor ventilation and siliciclastic sedimentation, low oxygenation, and high organic carbon deposition during the late Eocene (Shipboard Scientific Party, 2001a, 2001b). Site 1168 Eocene sediments are similar in nature to those at Cape Sorell (Boreham et al., 2002) and to those reported from DSDP Site 282 to the northwest, suggesting widespread late Eocene suboxic to anoxic conditions in the eastern Australo-Antarctic Gulf. Following a transitional phase during the Oligocene, in the Neogene these conditions had been replaced by deposition of carbonate ooze in a welloxygenated open ocean on a passive margin at middle bathyal depths (Shipboard Scientific Party, 2001ab; Boreham et al., 2002). The curves of Figure F2 both confirm the broad trend of initial shallow-marine, nearly continental conditions evolving into an open oceanic environment. A marked acceleration of this process apparently occurred near the end of the early Miocene as indicated by a distinct step in the relative abundance of oceanic dinocysts (Fig. F2). Variations in both curves 
during the late Eocene-early Oligocene may be explained by the influence of third-order eustatic sea level changes, as further research will possibly show in more detail. A marginal marine deltaic setting during the late Eocene is consistent with the relatively poorly diversified nature of the dinocyst assemblages, with sporadic optima of peridinioid species such as Deflandrea phosphoritica and gonyaulacoid taxa as Cooksonidium capricornum, Operculodinium, and Spiniferites spp. (the latter when more open-marine, neritic conditions arrived) (cf. Brinkhuis, 1994; Stover et al., 1996). The dinocyst assemblage in this interval is very similar to those recorded elsewhere from ancient Eocene-Oligocene delta-front deposits (Brinkhuis et al., 1992; Brinkhuis and Biffi, 1993; Brinkhuis, 1994). The Oligocene assemblages are characterized by a slight increase in diversity, with increasingly consistent occurrences of more open-marine neritic to offshore taxa such as T. pelagica, Cleistosphaeridium, and Hystrichokolpoma spp., besides ever-increasing numbers of typical oceanic taxa such as Nematosphaeropsis and Impagidinium spp. (Fig. F2). A general long term (post-Eocene) oligotrophic nature of the surface waters influencing Site 1168 is suggested from the low abundance of (proto) peridinioid, presumably heterotrophic species.

An important general aspect in the dinocyst assemblages is the near absence of Antarctic endemic (Transantarctic) species and the apparent influence of relatively warm waters throughout the succession at Site 1168. As explained above, the dinocyst assemblages are to a high degree comparable with those reported from low latitudes, although cosmopolitan taxa (e.g., Spiniferites spp., Operculodinium spp., and Nematosphaeropsis spp.) are common as well. This aspect suggests a longterm overall warm to warm-temperate nature of the surface waters influencing Site 1168 . The Tethyan index taxa display a rather patchy distribution pattern, suggesting that these horizons indicate maximum surface water warmth and/or maximum influence of water masses originating from low latitudes, possibly reflecting transportation. Conversely, already in Eocene and Oligocene times, occasional influence of colder (cold temperate) water masses is apparent as well, judging from the distribution patterns of cool-temperate species such as Gelatia inflata and Impagidinium velorum, besides some of the Transantarctic Flora species discussed above. Overall, the assemblages may thus be described as being warm temperate in nature.

Specifically, the late Eocene assemblages are characterized by the concomitant presence of typical lower-latitude and cosmopolitan taxa, suggesting subtropical to warm-temperate conditions. This aspect matches reports on the nature of the Eocene and early Oligocene vegetation in the region, which suggests that air temperatures were subtropical to warm temperate and always above freezing (Greenwood and Wing, 1995). Indeed, the inference of warm-temperate surface water conditions also matches earlier reports based on other microfossil groups and stable isotope studies.

On the basis of stable isotope studies (e.g., Kamp et al.,1990; Buening et al., 1998), inferred surface water temperatures ranged from $\sim 12^{\circ}$ to $20^{\circ} \mathrm{C}$ for the region during the late Eocene. Calcareous microfossil studies in the region indicate similar temperatures, indicating a long-term influence of a proto-Leeuwin Current (e.g., McGowran et al., 1997; Li et al., 2000, 2003; Nelson and Cooke, 2001). Li et al. (2003), studying foraminifers from ODP Leg 182 drill sites, specifically state (p. 1) “...The southern temperate assemblage hosted several subtropical species in the middle-late Eocene and Oligocene as immigrants probably transported by a warm-water system similar to the present-day Leeuwin Current..." 
This interpretation perfectly describes the dinocyst signal at Site 1168 as well.

In the Neogene, assemblages are also marked by an abundance of warmer-water species (in this case many Impagidinium species, indicating relatively warm, oligotrophic oceanic surface water conditions throughout) (cf. Rochon et al., 1999). In the Quaternary interval, a few specimens of the bipolar (cold) species I. pallidum are recorded as well. This aspect indicates the influence, albeit limited, of colder surface water masses in this interval or deep transport by possibly colder underlying waters.

\section{CONCLUDING REMARKS}

Clearly, the present results indicate potential for the application of quantitative palynological analysis for climatic and environmental reconstructions (except perhaps for the middle-upper Miocene interval) using materials from Site 1168. Further study involving higher-resolution analysis is under way, notably on the Eocene-Oligocene and Oligocene-Miocene transitions. Results of these more detailed studies will be presented in future contributions.

Significantly, the overall dinocyst distribution pattern matches a long-term (>40 m.y.) existence of a proto-Leeuwin Current influencing the larger southern Australian region, including Site 1168, resulting in warm-temperate dinocyst assemblages during the Paleogene and distinct virtual absence of Antarctic endemic species. The influence of this current apparently quite abruptly diminished directly to the south of the studied area. Varying influence of colder (cold temperate) sea-surface conditions is, however, also apparent, notably during the late Pliocene-Quaternary.

\section{ACKNOWLEDGMENTS}

This research used samples and data provided by the Ocean Drilling Program (ODP). ODP is sponsored by the U.S. National Science Foundation (NSF) and participating countries under management of Joint Oceanographic Institutions (JOI) Incorporated. U.S. and international agencies provided funding for this research. H.B., A.S., and J.W. thank NWO, the Netherlands Organization for Scientific Research.

We thank Natasja Welters and Jan van Tongeren (Utrecht) for sample processing. Leonard Bik (Utrecht) is kindly thanked for electronic photography handling and general assistance. Susan Kerstholt is thanked for assistance with palynological analysis. The crew of Leg 189 is thanked for general support. Reviewers Lorri Peters, Francine M.G. McCarthy, Mitch Malone, and Jörg Pross are thanked for helpful remarks that improved the manuscript. Matthew Huber is thanked for providing important additions to the text. Cathy Stickley is kindly thanked for drawing Figures F1 and F2. This is the Netherlands School of Sedimentary Geology (NSG) contribution number 2003.09.01. 


\section{REFERENCES}

Biffi, U., and Manum, S.B., 1988. Late Eocene-early Miocene dinoflagellate cyst biostratigraphy from the Marche region (central Italy). Boll. Soc. Paleontol. Ital., 27:163-212.

Boreham, C.J., Blevin, J.E., Duddy, I., Newman, J., Liu, K., Middleton, H., Macphail, M.K., and Cook, A.C., 2002. Exploring the potential for oil generation, migration and accumulation in Cape Sorell-1, Sorell Basin, offshore West Tasmania. APPEA J., 42:405-435.

Brinkhuis, H., 1994. Late Eocene to early Oligocene dinoflagellate cysts from the Priabonian type-area (Northeast Italy): biostratigraphy and paleoenvironmental interpretation. Palaeogeogr., Palaeoclimatol., Palaeoecol., 107:121-163.

Brinkhuis, H., and Biffi, U., 1993. Dinoflagellate cyst stratigraphy of the Eocene/ Oligocene transition in central Italy. Mar. Micropaleontol., 22:131-183.

Brinkhuis, H., Powell, A.J., and Zevenboom, D., 1992. High-resolution dinoflagellate cyst stratigraphy of the Oligocene/Miocene transition interval in Northwest and central Italy. In Head, M.J., and Wrenn, J.H. (Eds.), Neogene and Quaternary Dinoflagellate Cysts and Acritarchs: Salt Lake City (Publishers Press), 219-258.

Buening, N., Carlson, S.J., Spero, H.J., and Lee, D.E., 1998. Evidence for the early Oligocene formation of a proto-subtropical convergence from oxygen isotope records of New Zealand Paleogene brachiopods. Palaeogeogr., Palaeoclimatol., Palaeoecol., 138:43-68.

Cookson, I.C., and Eisenack, A., 1965. Microplankton from the Browns Creek clays, SW Victoria. Proc. R. Soc. Victoria, 79:119-131.

Crouch, E.M., and Hollis, C.J., 1996. Paleogene palynomorph and radiolarian biostratigraphy of DSDP Leg 29, Sites 280 and 281, South Tasman Rise. Inst. Geol. Nucl. Sci., Sci. Rep, 96:1-46.

Goodman, D.K., and Ford, L.N., Jr., 1983. Preliminary dinoflagellate biostratigraphy for the middle Eocene to Lower Oligocene from the Southwest Altantic Ocean. In Ludwig, W.J., Krasheninnikov, V.A., et al., Init. Repts. DSDP, 71: Washington (U.S. Govt. Printing Office), 859-977.

Greenwood, D.R., and Wing, S.L., 1995. Eocene continental climates and latitudinal temperature gradients. Geology, 23:1044-1048.

Hannah, M.J., 1997a. Climate controlled dinoflagellate distribution in late Eoceneearliest Oligocene strata from CIROS-01 drillhole, McMurdo Sound, Antarctica. Terra Antart., 4:73-78.

— 1997b. The Eocene/Oligocene boundary at 70 South, McMurdo Sound, Antartica. Terra Antart., 4:79-87.

Hannah, M.J., and Raine, J.I. (Eds.), 1997. Southern Ocean Late Cretaceous/early Cenozoic biostratrigraphic datums: a report of the Southern Ocean paleontology workshop. Sci. Rep.-Inst. Geol. Nucl. Sci., 4:1-33.

Hannah, M.J., Wilson, G.J., and Wrenn, J.H., 2000. Oligocene and Miocene marine palynomorphs from CRP-2/2A, Victorialand Basin, Antarctica. Terra Antart., 7:503511.

Hannah, M.J., Wrenn, J.H., and Wilson, G.J., 1998. Early Miocene and Quaternary marine palynomorphs from Cape Roberts project CRP-1, McMurdo Sound, Antarctica. Terra Antart., 5:527-538.

Harland, R., and Pudsey, C.J., 2002. Protoperidiniacean dinoflagellate cyst taxa from the Upper Miocene of ODP Leg 178, Antarctic Peninsula. Rev. Palaeobot. Palynol., 120:263-284.

Hopkins, J.A., and McCarthy, F.M.G., 2002. Post-depositional palynomorph degradation in Quaternary shelf sediments: a laboratory experiment studying the effects of progressive oxidation. Palynology, 26:167-184. 
Kamp, P.J.J., Waghorn, D.B., and Nelson, C.S., 1990. Late Eocene-early Oligocene integrated isotope stratigraphy and biostratigraphy for paleoshelf sequences in southern Australia. Palaeogeogr., Palaeoclimatol., Palaeoecol., 80:311-323.

Li, Q., McGowran, B., and James, N.P., 2003. Eocene-Oligocene planktonic forminiferal biostratigraphy of Sites 1126, 1130, 1132, and 1134, ODP Leg 182, Great Australian Bight. In Hine, A.C., Feary, D.A., and Malone, M.J. (Eds.), Proc. ODP, Sci. Results, 182, 1-28 [Online]. Available from World Wide Web: <http://wwwodp.tamu.edu/publications/182_SR/VOLUME/CHAPTERS/006.PDF>. [2003-06-30]

Li, Q., McGowran, B., and White, M.R., 2000. Sequences and biofacies packages in the mid-Cenozoic Gambier Limestone, South Australia: reappraisal of foraminiferal evidence. Aust. J. Earth Sci., 47:955-970.

Mao, S., and Mohr, B.A.R., 1995. Middle Eocene dinocysts from Bruce Bank (Scotia Sea, Antarctica) and their palaeoenvironmental and palaeogeographic implications. Rev. Palaeobot. Palynol., 86:235-263.

McGowran, B., Li, Q., Cann, J., Padley, D., McKirdy, D.M., and Shafik, S., 1997. Biostratigraphic impact of the Leeuwin Current in southern Australia since the late middle Eocene. Palaeogeogr., Palaeoclimatol., Palaeoecol., 136:19-40.

McMinn, A., 1992. Neogene dinoflagellate distribution in the eastern Indian Ocean from Leg 123, Site 765. In Gradstein, F.M., Ludden, J.N., et al., Proc. ODP, Sci. Results, 123: College Station, TX (Ocean Drilling Program), 429-441.

- 1993 . Neogene dinoflagellate cyst biostratigraphy from Sites 815 and 823, Leg 133, northeastern Australian margin. In McKenzie, J.A., Davies, P.J., Palmer-Julson, A., et al., Proc. ODP, Sci. Results, 133: College Station, TX (Ocean Drilling Program), 97-105.

-1995 . Why are there no post-Paleogene dinoflagellate cysts in the Southern Ocean? Micropaleontology, 41:383-386.

McMinn, A., Howard, W.R., and Roberts, D., 2001. Late Pliocene dinoflagellate cyst and diatom analysis from a high resolution sequence in DSDP Site 594, Chatham Rise, southwest Pacific. Mar. Micropaleontol., 43:207-221.

McMinn, A., and Wells, P., 1997. Use of dinoflagellate cysts to determine changing Quarternary sea-surface temperature in southern Australia. Mar. Micropaleontol., 29:407-422.

Miller, K.G., Mountain, G.S., Browning, J.V., Kominz, M., Sugarman, P.J., ChristieBlick, N., Katz, M.E., and Wright, J.D., 1998. Cenozoic global sea level, sequences, and the New Jersey transect: results from coastal plain and continental slope drilling. Rev. Geophys., 36:569-601.

Mohr, B.A.R., 1990. Eocene and Oligocene sporomorphs and dinoflagellate cysts from Leg 113 drill sites, Weddell Sea, Antarctica. In Barker, P.F., Kennett, J.P., et al., Proc. ODP, Sci. Results, 113: College Station, TX (Ocean Drilling Program), 595-612.

Nelson, C.S., and Cooke, P.J., 2001. History of oceanic front development in the New Zealand sector of the Southern Ocean during the Cenozoic-a synthesis. N. Z. J. Geol. Geophys., 44:535-553.

Rochon, A., de Vernal, A., Turon, J.L., Mathiessen, J., and Head, M.J., 1999. Distribution of recent dinoflagellate cysts in surface sediments from the North Atlantic Ocean and adjacent seas in relation to sea-surface parameters. Am. Assoc. Stratigr. Palynol. Contrib. Ser., Vol. 35.

Shipboard Scientific Party, 2001a. Leg 189 summary. In Exon, N.F., Kennett, J.P., Malone, M.J., et al., Proc. ODP, Init. Repts., 189, 1-98 [CD-ROM]. Available from: Ocean Drilling Program, Texas A\&M University, College Station TX 77845-9547, USA.

_ 2001b. Site 1168. In Exon, N.F., Kennett, J.P., Malone, M.J., et al., Proc. ODP, Init. Repts., 189, 1-170 [CD-ROM]. Available from: Ocean Drilling Program, Texas A\&M University, College Station TX 77845-9547, USA.

—, 2001c. Site 1170. In Exon, N.F., Kennett, J.P., Malone, M.J., et al., Proc. ODP, Init. Repts., 189, 1-167 [CD-ROM]. Available from: Ocean Drilling Program, Texas A\&M University, College Station TX 77845-9547, USA. 
—, 2001d. Site 1171. In Exon, N.F., Kennett, J.P., Malone, M.J., et al., Proc. ODP, Init. Repts., 189, 1-176 [CD-ROM]. Available from: Ocean Drilling Program, Texas A\&M University, College Station TX 77845-9547, USA.

Stover, L.E., 1975. Observations on some Australian Eocene dinoflagellates. Geoscience and Man, 11:35-45

Stover, L.E., Brinkhuis, H., Damassa, S.P., de Verteuil, L., Helby, R.J., Monteil, E., Partridge, A.D., Powell, A.J., Riding, J. B., Smelror, M., and Williams, G.L., 1996. Mesozoic-Tertiary dinoflagellates, acritarchs and prasinophytes. In Jansonius, J., and McGregor, D.C. (Eds.), Principles and Applications (Vol. 2): College Station, TX (Am. Assoc. Stratigraphic Palynol. Found.), 641-750.

Truswell, E.M., 1997. Palynomorph assemblages from marine Eocene sediments on the West Tasmanian continental margin and the South Tasman Rise. Aust. J. Earth Sci., 4:633-654.

Van Simaeys, S., De Man, E., Vandenberghe, N., Brinkhuis, H., and Steurbaut, E., in press. Stratigraphic and paleoenvironmental analysis of the Rupelian-Chattian transition in the type region: evidence from dinoflagellate cysts, foraminifera and calcareous nannofossils. Palaeogeogr., Palaeoclimatol., Palaeoecol.

Versteegh, G.J.M., and Zonneveld, K.A.F., 2002. Use of selective degradation to separate preservation from productivity. Geology, 30:615-618.

Williams, G.L., Lentin, J.K., and Fensome, R.A., 1998. The Lentin and Williams Index of Fossil Dinoflagellate Cysts (1998 ed.). Am. Assoc. Stratigr. Palynol., Contrib. Ser., Vol. 34.

Wilpshaar, M., Santarelli, A., Brinkhuis, H., and Visscher, H., 1996. Dinoflagellate cysts and mid-Oligocene chronostratigraphy in the central Mediterranean region. J. Geol. Soc. London: 153:553-561.

Wilson, G.J., 1985. Dinoflagellate biostratigraphy of the Eocene Hampden Section, North Otago, New Zealand. N. Z. Geol. Surv. Rec., 8:93-101.

- 1988. Paleocene and Eocene dinoflagellate cysts from Waipawa, Hawkes Bay, New Zealand. N. Z. Geol. Surv. Bull., 57:1-96.

Wrenn, J.H., and Beckmann, S.W., 1982. Maceral, total organic carbon, and palynological analyses of Ross Ice Shelf Project site J9 cores. Science, 216:187-189.

Wrenn, J.H., Hannah, M.J., and Raine, J.I., 1998. Diversity and palaeoenvironmental significance of late Cainozoic marine palynomorphs from the CRP-1 core, Ross Sea, Antarctica. Terra Antart., 5:553-570.

Wrenn, J.H., and Hart, G.F., 1988. Paleogene dinoflagellate cyst biostratigraphy of Seymour Island, Antarctica. Mem.-Geol. Soc. Am., 169:321-447.

Wrenn, J.H., and Kokinos, J.P., 1986. Preliminary comments on Miocene through Pleistocene dinoflagellate cysts from De Soto Canyon, Gulf of Mexico. In Wrenn, J.H., Duffield, S.L., and Stein, J.A. (Eds.), Am. Assoc. Stratigr. Palynol. Contrib. Ser., 17:169-225.

Zevenboom, D., 1995. Dinoflagellate cysts from the Mediterranean late Oligocene and Miocene [Ph.D. thesis]. Univ. Utrecht, The Netherlands.

Zonneveld, K.A.F., Versteegh, G.J.M., and de Lange, G., 1997. Preservation of organicwalled dinoflagellate cysts in different oxygen regimes: a 10,000 year natural experiment. Mar. Micropaleontol., 29:393-405.

Zonneveld, K.A.F., Versteegh, G.J.M., and de Lange, G.J., 2001. Palaeoproductivity and post-depositional aerobic organic matter decay reflected by dinoflagellate cyst assemblages of the Eastern Mediterranean S1 sapropel. Mar. Geol., 172:181-195. 
H. BRINKHUIS ET AL.

LATE Eocene-QuATERnARy Dinoflagellate Cysts

\section{APPENDIX}

\section{Species List and Taxonomic Remarks}

Acanthaulax? sp.

Remarks: This taxon superficially resembles Operculodinium israelianum, but differs by having processes arranged along sutural or penitabular rows. It is provisionally assigned to Acanthaulax. Similar forms have been recorded in the Mediterranean Neogene (Zevenboom, 1995).

Achomosphaera andalousiensis

Aireiana verrucosa

Algidasphaeridium minutum var. cezare

Algidasphaeridium minutum var. minutum

Amiculosphaera umbracula

Apteodinium australiense

Areoligera? semicirculata

Areoligera spp. (pars)

Ataxiodinium choane

Ataxiodinium confusum

Batiacasphaera spp.

Bitectatodinium tepekiense

Brigantedinium spp.

Caligodinium pychnum

Caligodinium spp. (pars)

Cannosphaeropsis sp. A

Remarks: This rather large species of Cannosphaeropsis is foremost characterized by having broad distal rims connecting gonal processes; occasionally small spines are developed along the outer rims.

Cannosphaeropsis spp. (pars)

Cerebrocysta poulsenii

Cerebrocysta sp. A

Remarks: This species of Cerebrocysta is characterized by being large, by having a $2 \mathrm{P}$ archaeopyle (loss of $2 "+3$ "), and by developing cerebral rugulae of intermediate size. Similar forms have been recorded in the Mediterranean Middle Miocene as Cerebrocysta powellii ms (Zevenboom, 1995).

Cerebrocysta spp. (pars)

Chiropteridium spp

Cleistosphaeridium spp.

Cooksonidium capricornum

Cordosphaeridium cantharellum

Cordosphaeridium fibrospinosum

Cordosphaeridium minimum

Cordosphaeridium spp. (pars)

Corrudinium harlandii 


\section{H. BRINKHUIS ET AL.

Corrudinium incompositum

Cribroperidinium spp.

Dalella chathamensis

Dapsilidinium spp.

Deflandrea antarctica group

Deflandrea convexa group

Deflandrea phosphoritica group

Dinopterygium spp.

Diphyes colligerum

Diphyes ficusoides

Distatodinium biffii

Distatodinium spp. (pars)

Ectosphaeropsis burdigalensis

Edwardsiella sexispinosum

Emmetrocysta urnaformis

Enneadocysta partridgei

Eocladopyxis spp.

Eurydinium spp.

Filisphaera spp.

Gelatia inflata

Glaphyrocysta spp.

Gramocysta verricula

Habibacysta tectata

Hemiplacophora semilunifera

Histiocysta spp.

Heteraulacacysta spp.

Homotryblium spp.

Hystrichokolpoma cinctum

Hystrichokolpoma pusilla

Hystrichokolpoma rigaudiae group

Hystrichokolpoma salacia group

Hystrichokolpoma sp. cf. Homotryblium oceanicum (Wilsphaar et al., 1996)

Hystrichokolpoma sp. A

Remarks: This species of Hystrichokolpoma is characterized by its relatively small size and by typically having poorly developed, deflated hollow penitabular processes.

Hystrichosphaeropsis spp.

Hystrichostrogylon spp.

Hystrichosphaeridium spp.

Impagidinium aculeatum

Impagidinium dispertitum 


\section{H. BRINKHUIS ET AL.

Impagidinium japonicum

Impagidinium maculatum

Impagidinium pallidum

Impagidinium paradoxum

Impagidinium patulum

Impagidinium sphaericum

Impagidinium strialatum

Impagidinium victorianum

Impagidinium velorum

Impagidinium spp. (pars)

Invertocysta spp.

Labyrinthodinium truncatum

Lejeunecysta spp.

Lingulodinium machaerophorum

Lophocysta spp.

Melitasphaeridium choanophorum

Melitasphaeridium pseudorecurvatum

Membranilarnacia? picenum

Membranilarnacia? sp.

Remarks: This taxon is provisionally placed in Membranilarnacia in view of it having an ectophragm distally connecting process complexes and an apical archaeopyle involving the loss of $1^{\prime}-4^{\prime}$. General shape, size, and process distribution suggests affinity with Schematophora.

Mendicodinium sp. A, Wrenn and Kokinos, 1986

Nematosphaeropsis spp.

Octodinium askiniae

Operculodinium echigoense sensu McMinn, 1992

Operculodinium janduchenei

Operculodinium microtrianum

Operculodinium piaseckii

Operculodinium spp. (pars)

Pentapharsodinium dalei cysts

Pentadinium laticinctum

Phthanoperidinium comatum

Phthanoperidinium filigranum

Phthanoperidinium spp.

Polysphaeridium spp.

Pyxidinopsis spp.

Reticulatosphaera actinocoronata

Rhombodinium spp.

Samlandia chlamydophora 
H. BRINKHUIS ET AL.

LATE Eocene-QuATERnARy Dinoflagellate Cysts

Schematophora speciosa

Selenopemphix brevispinosum

Selenopemphix nephroides

Selenopemphix quanta

Spiniferites pseudofurcatus

Spiniferites mirabilis

Spiniferites cf. mirabilis

Remarks: This taxon resembles $S$. mirabilis, but differs by having a much larger size range (up to $120 \mu \mathrm{m}$ ) and by less well defined and developed processes.

Spiniferites spp.

Stelladinium stellatum

Stoveracysta ornata

Stoveracysta cf. conerae

Remarks: this taxon resembles $S$. conerae, but differs by having a smaller size range (up to $60 \mu \mathrm{m}$ ) and by relatively high penitabular ornamentations.

Svalbardella spp.

Tectatodinium spp.

Thalassiphora pelagica

Trinovantedinium applanatum

Tuberculodinium vancampoae

Wetzeliella gochtii/symmetrica group 
H. BRINKHUIS ET AL.

LATE EOCENE-QUATERnARy Dinoflagellate CySTS

Figure F1. ODP Leg 189 drilling locations (Sites 1168-1172).

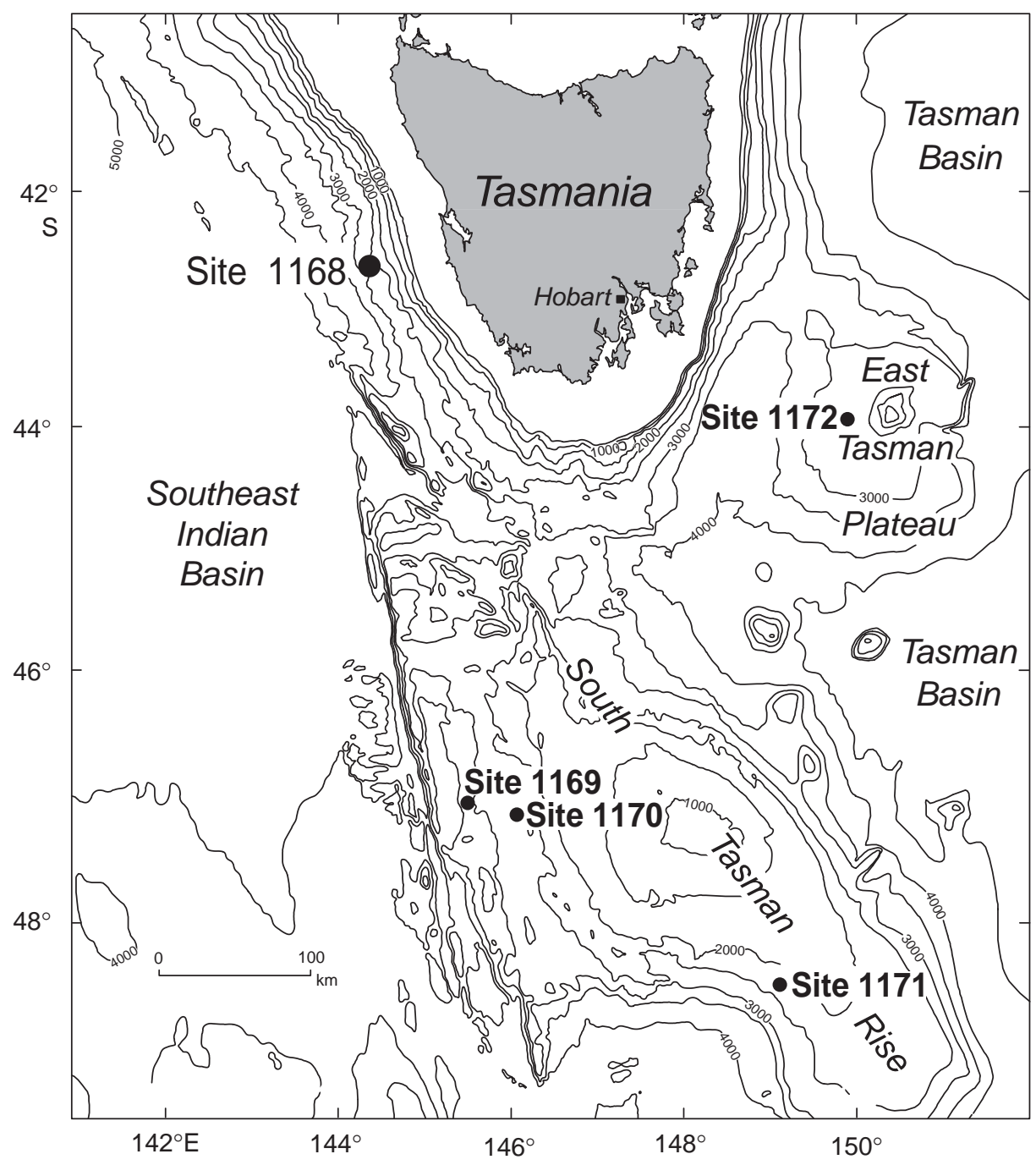


H. BRINKHUIS ET AL.

LATE Eocene-QuATERnARy Dinoflagellate Cysts

Figure F2. Percentages of terrestrial palynomorphs and oceanic (non-neritic) dinocysts in palynological assemblages of Hole 1168A. TD = total depth.

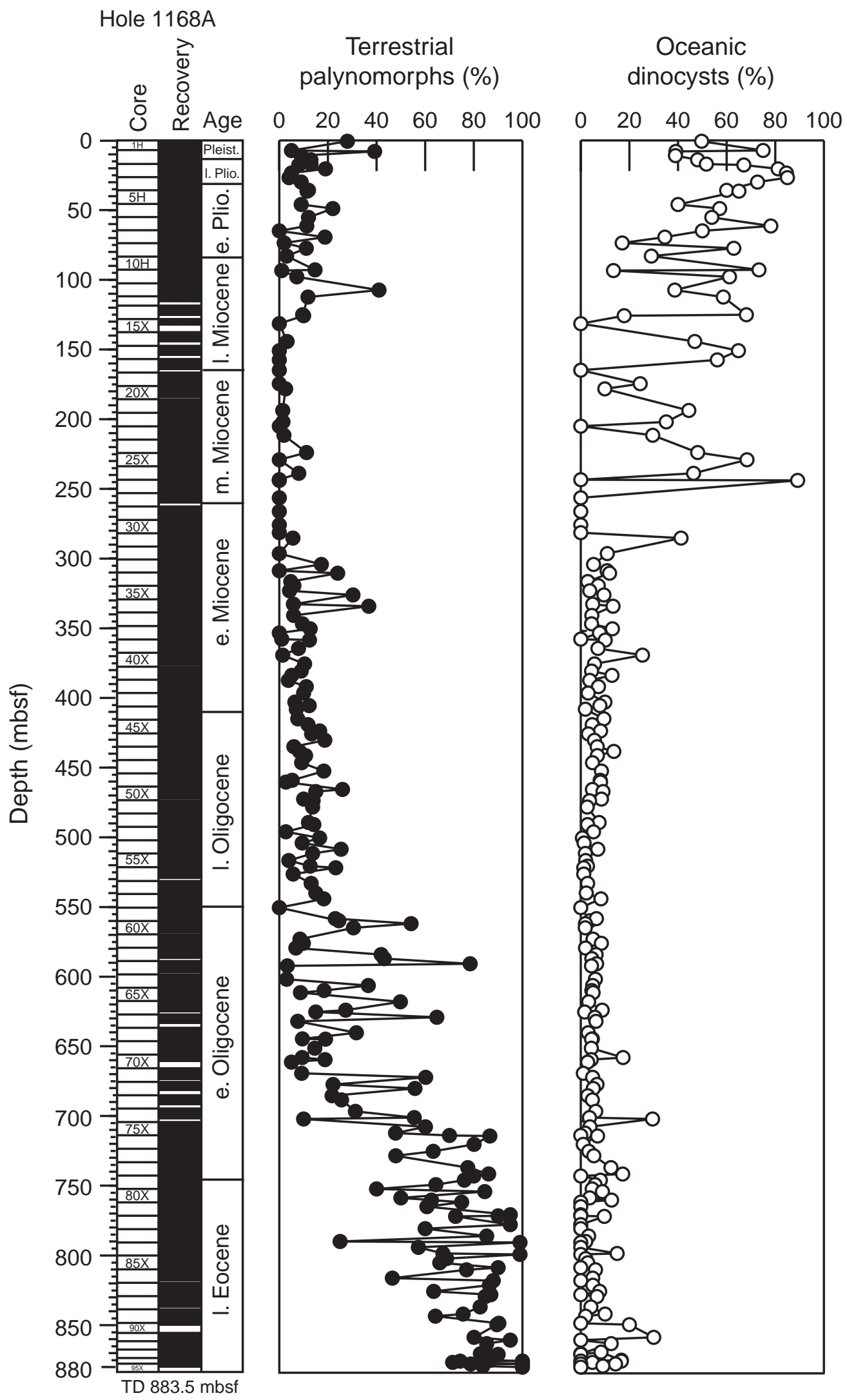


H. BRINKHUIS ET AL.

LATE Eocene-QuATERnARy Dinoflagellate Cysts

Table T1. Selected palynological results, Hole 1168A. (This table is available in an oversized format.) 
H. BRINKHUIS ET AL.

LATE Eocene-QuATERnARy Dinoflagellate Cysts

Table T2. Selected potentially age-indicative dinocyst events, Hole 1168A.

\begin{tabular}{|c|c|c|c|c|c|c|c|c|}
\hline \multirow[b]{2}{*}{ Datum } & \multicolumn{2}{|c|}{ Core, section, interval $(\mathrm{cm})$} & \multicolumn{4}{|c|}{ Depth (mbsf) } & \multirow{2}{*}{$\begin{array}{c}\text { Magneto } \\
\text { chron* }\end{array}$} & \multirow{2}{*}{$\begin{array}{l}\text { Age } \\
(\mathrm{Ma})\end{array}$} \\
\hline & Top & Bottom & Top & Bottom & Mean & Error & & \\
\hline & 189-1168A- & 189-1168A- & & & & & & \\
\hline LO Amiculosphaera umbracula & $2 \mathrm{H}-\mathrm{CC}, 9-11$ & $3 \mathrm{H}-3,60-62$ & 17 & 20.4 & 18.7 & 1.7 & $\mathrm{C} 1 \mathrm{r} .2 \mathrm{r}$ & 1.6 \\
\hline LO Invertocysta spp. & $3 \mathrm{H}-\mathrm{CC}, 29-32$ & $4 \mathrm{H}-3,60-62$ & 26.71 & 29.85 & 28.28 & 1.57 & $\mathrm{C} 2 \mathrm{r} ?$ & 2.5 \\
\hline LO Achomosphaera andalousiensis & $8 \mathrm{H}-\mathrm{CC}, 8-13$ & $9 \mathrm{H}-3,60-62$ & 73.58 & 77.4 & 75.49 & 1.91 & ? & ? \\
\hline FO Amiculosphaera umbracula & $9 \mathrm{H}-3,60-62$ & $9 \mathrm{H}-\mathrm{CC}, 27-32$ & 77.4 & 82.98 & 80.19 & 2.79 & ? & ? \\
\hline LO Reticulatosphaera actinocoronata & $9 \mathrm{H}-\mathrm{CC}, 27-32$ & $10 \mathrm{H}-7,60-62$ & 82.98 & 92.9 & 87.94 & 4.96 & ? & ? \\
\hline FO Achomosphaera andalousiensis & $14 \mathrm{X}-\mathrm{CC}, 25-30$ & $15 X-3,60-62$ & 125.8 & 131.5 & 128.65 & 2.85 & ? & ? \\
\hline LO Labyrinthodinium truncatum & $19 X-6,60-62$ & $20 X-2,60-62$ & 174.6 & 178.3 & 176.45 & 1.85 & ? & $?$ \\
\hline LO Cerebrocysta poulsenii & $19 X-6,60-62$ & $20 x-2,60-62$ & 174.6 & 178.3 & 176.45 & 1.85 & $?$ & $?$ \\
\hline FO Cerebrocysta poulsenii & $22 X-5,60-62$ & $22 X-C C, 29-34$ & 202 & 205.1 & 203.55 & 1.55 & $?$ & $?$ \\
\hline FO Labyrinthodinium truncatum & $23 X-5,60-62$ & $24 X-7,40-42$ & 211.6 & 224 & 217.8 & 6.2 & $?$ & ? \\
\hline LO Mendicodinium sp. A & $23 X-5,60-62$ & $24 X-7,40-42$ & 211.6 & 224 & 217.8 & 6.2 & $?$ & $?$ \\
\hline FO Mendicodinium sp. A & $25 X-4,60-62$ & $26 X-4,60-62$ & 229.2 & 238.9 & 234.05 & 4.85 & ? & $?$ \\
\hline FCO Impagidinium patulum & $33 X-3,60-62$ & $33 X-6,60-62$ & 304.3 & 308.8 & 306.55 & 2.25 & $?$ & $?$ \\
\hline LO Apteodinium australiense & $35 X-5,60-62$ & $36 X-3,60-62$ & 326.2 & 332.8 & 329.5 & 3.3 & C6n? & 19.5 \\
\hline LO Hystrichokolpoma rigaudiae & $37 X-6,60-62$ & $38 X-2,60-62$ & 346.9 & 350.5 & 348.7 & 1.8 & $\mathrm{C} 6 r ?$ & 21 \\
\hline LO Glaphyrocysta spp. & $40 X-6,60-62$ & $41 X-3,60-62$ & 375.7 & 380.9 & 378.3 & 2.6 & $\mathrm{C} 6 \mathrm{Cn} ?$ & 24 \\
\hline LO Ectosphaeropsis burdigalensis & $44 X-2,63-64$ & $44 X-7,33-35$ & 408.23 & 415.13 & 411.68 & 3.45 & $\mathrm{C} 6 \mathrm{Cr}$ & 24.5 \\
\hline LO Chiropteridium spp. & $46 X-1,61-64$ & $46 X-4,65-68$ & 425.91 & 430.45 & 428.18 & 2.27 & C7n1n & 24.7 \\
\hline FO Chiropteridium spp. & $50 X-3,60-62$ & $50 X-C C, 43-48$ & 467.3 & 472.7 & 470 & 2.7 & C7Ar & 25.8 \\
\hline FO Ectosphaeropsis burdigalensis & $51 X-4,60-62$ & $52 X-5,60-62$ & 478.4 & 489.5 & 483.95 & 5.55 & $\mathrm{C} 8 \mathrm{n} 2 \mathrm{n}$ & 26.4 \\
\hline LO Distatodinium biffii & $53 X-6,60-62$ & $54 X-2,60-62$ & 500.6 & 504.2 & 502.4 & 1.8 & $\mathrm{C} 8 \mathrm{r}$ & 26.8 \\
\hline LO Hystrichokolpoma sp. cf. Homotryblium oceanicum & $57 X-2,60-62$ & $57 X-7,60-62$ & 533.2 & 540.1 & 536.65 & 3.45 & C9n & 27.5 \\
\hline LO Svalbardella spp. & $57 X-7,60-62$ & $58 X-3,60-62$ & 540.1 & 544.3 & 542.2 & 2.1 & $\mathrm{C} 9 \mathrm{n}$ & 27.8 \\
\hline FO Distatodinium biffii & $57 X-7,60-62$ & $58 X-3,60-62$ & 540.1 & 544.3 & 542.2 & 2.1 & C9n & 27.8 \\
\hline FO Svalbardella spp. & $58 X-3,60-62$ & $58 \mathrm{X}-\mathrm{CC}, 45-50$ & 544.3 & 550.6 & 547.45 & 3.15 & $\mathrm{C} 9 \mathrm{n} / \mathrm{r}$ & 27.95 \\
\hline LO Wetzeliella gochtii & $59 X-6,60-62$ & $60 X-2,60-62$ & 558.5 & 562.1 & 560.3 & 1.8 & $\mathrm{C} 9 \mathrm{r}$ & 28.15 \\
\hline LO Hystrichokolpoma pusilla & $60 \times-2,60-62$ & $60 \times-4,60-62$ & 562.1 & 565.1 & 563.6 & 1.5 & $\mathrm{C} 9 \mathrm{r}$ & 28.2 \\
\hline LO Areoligera? semicirculata & $60 x-4,60-62$ & $61 X-3,60-62$ & 565.1 & 573.2 & 569.15 & 4.05 & $\mathrm{C} 9 \mathrm{r}$ & 28.3 \\
\hline FO Hystrichokolpoma pusilla & $67 X-4,60-62$ & $68 X-3,60-62$ & 632.2 & 640.4 & 636.3 & 4.1 & $\mathrm{C} 10 \mathrm{n} 2 \mathrm{n}$ & 28.8 \\
\hline FO Invertocysta spp. & $70 x-2,60-62$ & $70 x-3,60-62$ & 658.2 & 659.7 & 658.95 & 0.75 & $\mathrm{C} 10 \mathrm{r}$ & 29.2 \\
\hline FO Hystrichokolpoma sp. cf. Homotryblium oceanicum & $72 X-2,63-65$ & $72 X-4,46-48$ & 677.53 & 680.36 & 678.945 & 1.415 & $\mathrm{C} 10 \mathrm{r}$ & 29.3 \\
\hline LO Corrudinium incompositum & $73 X-3,57-59$ & $74 X-2,63-65$ & 688.57 & 696.83 & 692.7 & 4.13 & $\mathrm{C} 10 \mathrm{r}$ & 29.4 \\
\hline FO Areoligera? semicirculata & $74 X-2,63-65$ & $74 X-5,60-62$ & 696.83 & 701.3 & 699.065 & 2.235 & $\mathrm{C} 10 \mathrm{r}$ & 29.45 \\
\hline FO Wetzeliella gochtii & $74 \mathrm{X}-\mathrm{CC}, 32-37$ & $75 X-3,60-62$ & 702.3 & 707.9 & 705.1 & 2.8 & C10r & 29.5 \\
\hline FO Apteodinium australiense & $74 \mathrm{X}-\mathrm{CC}, 32-37$ & $75 X-3,60-62$ & 702.3 & 707.9 & 705.1 & 2.8 & $\mathrm{C} 10 \mathrm{r}$ & 29.5 \\
\hline LO Enneadocysta partridgei & $77 X-4,60-62$ & $78 X-4,60-62$ & 728.72 & 737.2 & 732.96 & 4.24 & $\mathrm{C} 12 \mathrm{n} ?$ & 30.8 \\
\hline LO Stoveracysta ornata & $78 \mathrm{X}-\mathrm{CC}, 43-48$ & $79 x-3,60-62$ & 743.2 & 746.2 & 744.7 & 1.5 & $\mathrm{C} 12 \mathrm{r} ?$ & 31.3 \\
\hline LO Stoveracysta kakanuiensis & $79 X-3,60-62$ & $79 X-5,60-62$ & 746.2 & 749.4 & 747.8 & 1.6 & $\mathrm{C} 12 \mathrm{r} ?$ & 31.3 \\
\hline FO Stoveracysta kakanuiensis & $79 X-5,60-62$ & $79 X-C C, 34-39$ & 749.4 & 752.5 & 750.95 & 1.55 & $\mathrm{C} 13 \mathrm{r}$ ? & 34.2 \\
\hline LO Cooksonidium capricornum & 79X-CC, 34-39 & $80 X-2,60-62$ & 752.5 & 754.4 & 753.45 & 0.95 & $\mathrm{C} 15 \mathrm{n} ?$ & 34.8 \\
\hline FO Stoveracysta ornata & $84 X-3,60-62$ & $84 X-6,60-62$ & 794.4 & 798.8 & 796.6 & 2.2 & C15r? & 35.2 \\
\hline LO Hemiplacophora semilunifera & $84 X-3,60-62$ & $84 X-6,60-62$ & 794.4 & 798.8 & 796.6 & 2.2 & C15r? & 35.2 \\
\hline FO Reticulatosphaera actinocoronata & $84 X-6,60-62$ & $84 \mathrm{X}-\mathrm{CC}, 31-36$ & 798.8 & 799.5 & 799.15 & 0.35 & C15r? & 35.3 \\
\hline FO Spiniferites mirabilis & $84 X-6,60-62$ & $84 \mathrm{X}-\mathrm{CC}, 31-36$ & 798.8 & 799.5 & 799.15 & 0.35 & $\mathrm{C} 15 \mathrm{r}$ ? & 35.3 \\
\hline LO Schematophora speciosa & $86 \mathrm{X}-\mathrm{CC}, 37-42$ & $87 X-2,60-62$ & 818.3 & 821.6 & 819.95 & 1.65 & C16n1n? & 35.35 \\
\hline LO Aireiana verrucosa & $88 X-1,60-62$ & $88 X-6,60-62$ & 829.7 & 837.15 & 833.425 & 3.725 & $\mathrm{C} 16 \mathrm{n} 2 \mathrm{n} ?$ & 35.5 \\
\hline FO Aireiana verrucosa & $88 X-6,60-62$ & $89 X-3,60-62$ & 837.15 & 842.3 & 839.725 & 2.575 & $\mathrm{C} 16 \mathrm{n} 2 \mathrm{n} ?$ & 35.6 \\
\hline LO Deflandrea convexa & $92 X-2,60-62$ & $92 X-7,55-57$ & 863.5 & 870.8 & 867.15 & 3.65 & $C 16 n 2 n ?$ & 35.8 \\
\hline FO Schematophora speciosa & $94 X-3,64-66$ & $94 X-C C, 33-39$ & 876.97 & 878.1 & 877.535 & 0.565 & $\mathrm{C} 16 \mathrm{n} 2 \mathrm{n} ?$ & 36 \\
\hline FO Cooksonidium capricornum & $75 X-2,56-58$ & $75 X-C C, 24-29$ & 879.56 & 880.4 & 879.98 & 0.42 & $\mathrm{C} 16 \mathrm{n} 2 \mathrm{n} ?$ & 36 \\
\hline
\end{tabular}

Notes: ${ }^{*}=$ ages are derived from Stickley et al., this volume. $\mathrm{LO}=$ last occurrence, $\mathrm{FO}=$ first occurrence, $\mathrm{FCO}=$ first common occurrence. 
H. BRINKHUIS ET AL.

LATE Eocene-QuATERnARy Dinoflagellate Cysts

Plate P1. Illustrations of taxa, sample, slide, and England Finder (EF) coordinates. Scale bar $=\sim 20 \mu \mathrm{m}$ unless stated otherwise. 1-3. Acanthaulax? sp. (Sample 189-1168A-24X-7, 40-42 cm); 2, V39-0. 4-8. Apteodinium australiense (Sample 189-1168A-38X-2, 60-62 cm); (4, 5) 1, R40-1; (6-8) 1, P55-0. 9, 10. Areoligera? semicirculata (Sample 189-1168A-70X-3, 60-62 cm); 2, P32. 11, 12. Ataxiodinium choane (Sample 189-1168A-10H7, 60-62 cm); 1, S31-1/2. (Continued on next 12 pages.)

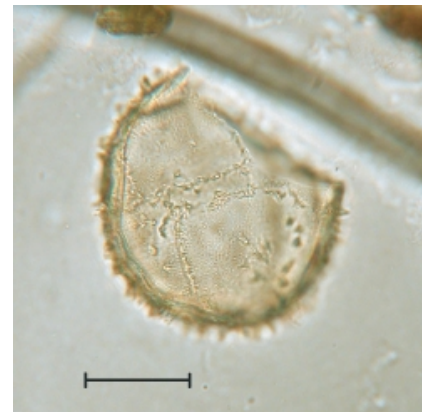

1

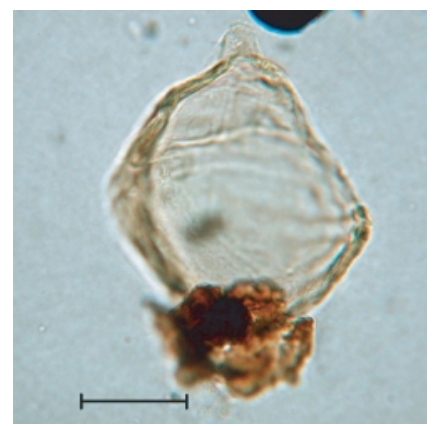

4

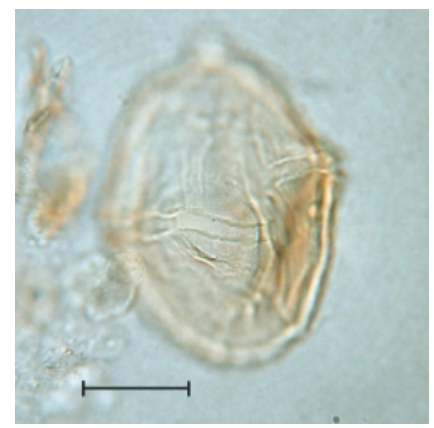

7

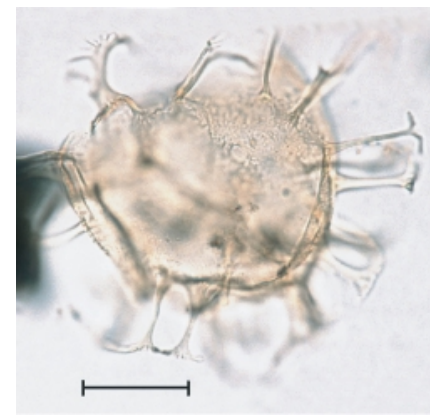

10

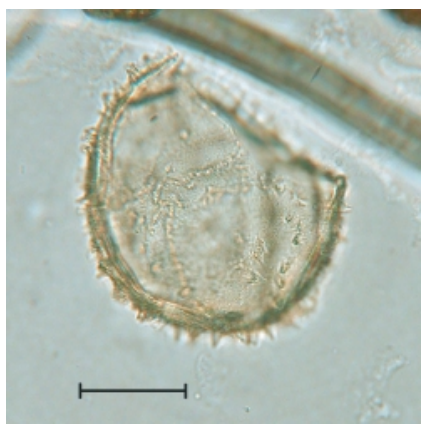

2

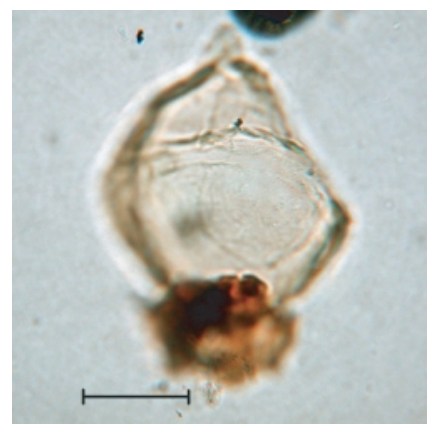

5

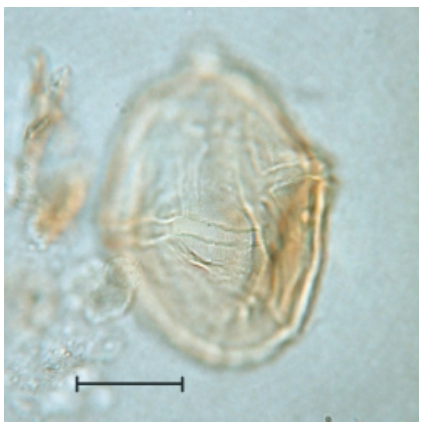

8

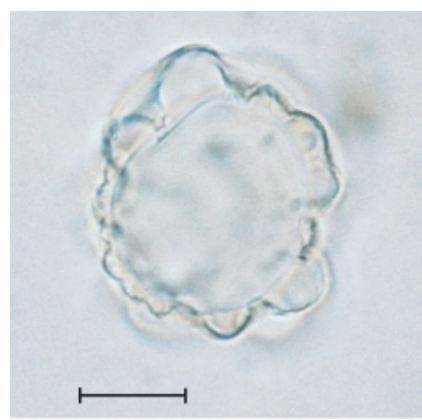

11

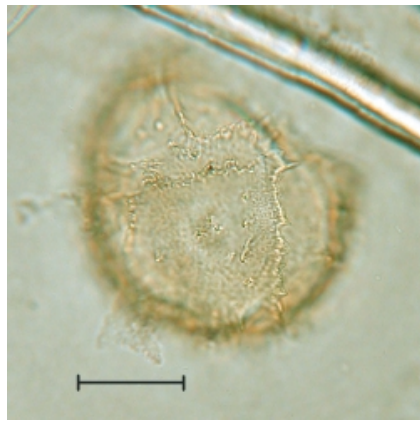

3

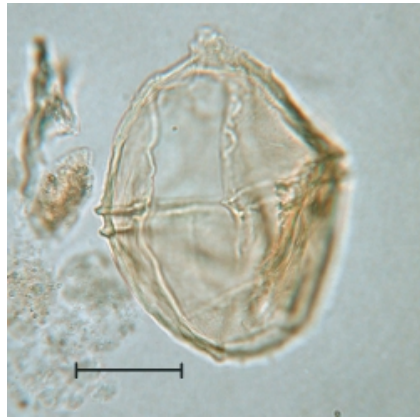

6

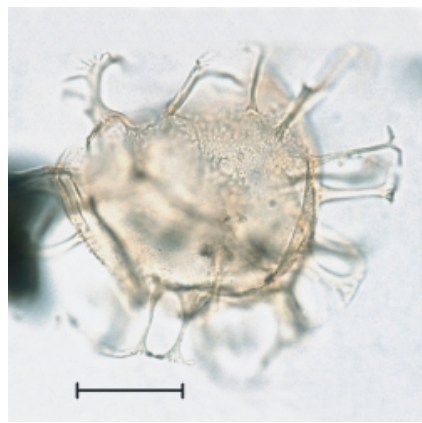

9

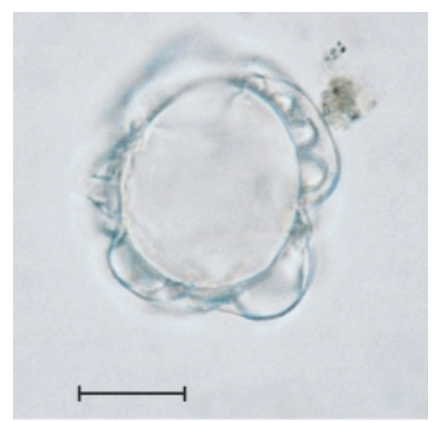

12 
H. BRINKHUIS ET AL.

LATE Eocene-QuATERnARy Dinoflagellate Cysts

Plate P1 (continued). 13, 14. Ataxiodinium choane (Sample 189-1168A-8H-4, 60-62 cm); 2, V33-4. 15. Ataxiodinium confusum (Sample 189-1168A-4H-3, 60-62 cm); 1, W26-2. 16, 17. Brigantedinium spp. (Sample 1891168A-03H-3, 60-62 cm); (16) 2, V30-3; (17) 2, U23-2. 18-20. Caligodinium pychnum (Sample 189-1168A38X-2, 60-62 cm); (18, 19) 1, S37-1; (20) 1, R36. 21, 22. Cannosphaeropsis sp. A (Sample 189-1168A-70X-3, 60-62 cm); 1, E14-4. 23, 24. Cerebrocysta poulsenii (Sample 189-1168A-20X-2, 60-62 cm); 1, O48-3 (scale bar $=\sim 15 \mu \mathrm{m})$. (Continued on next page.)

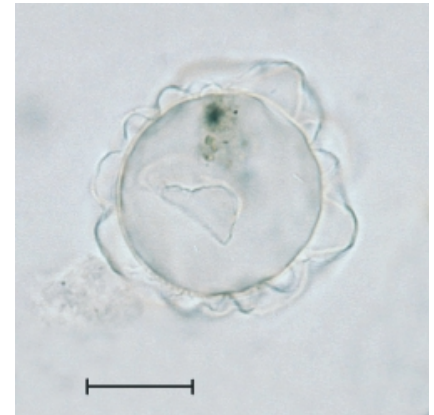

13

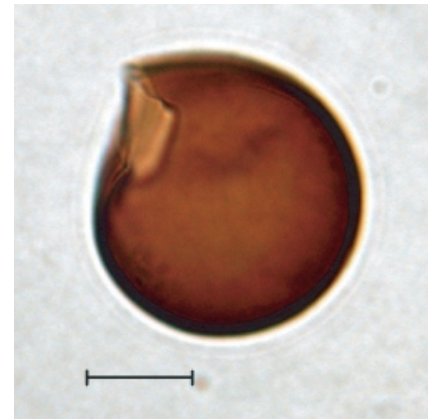

16

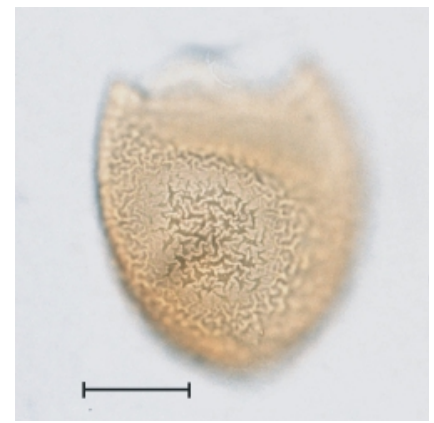

19

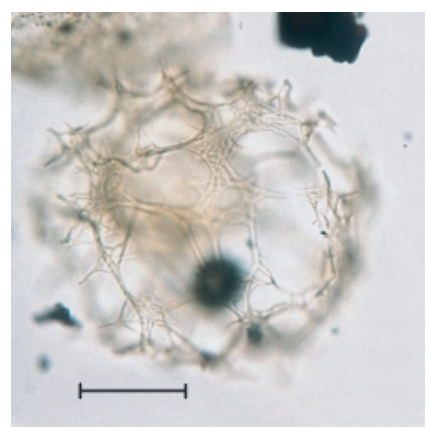

22

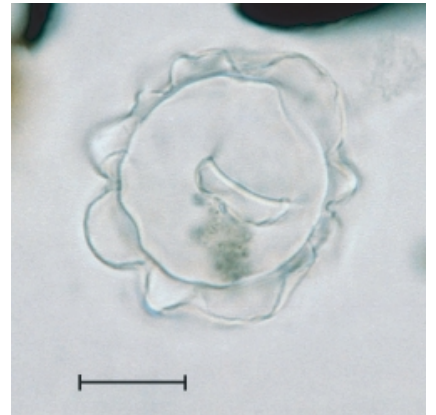

14

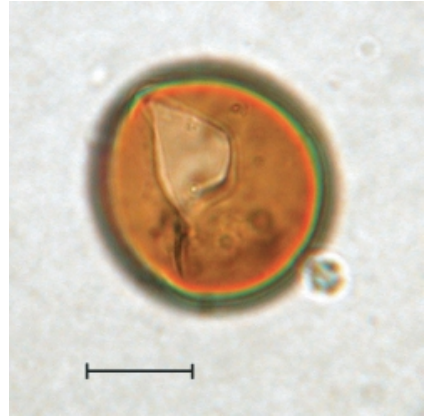

17

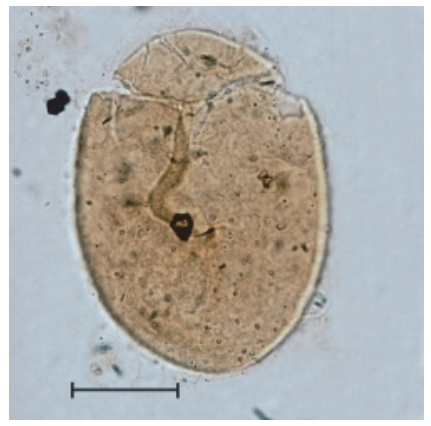

20

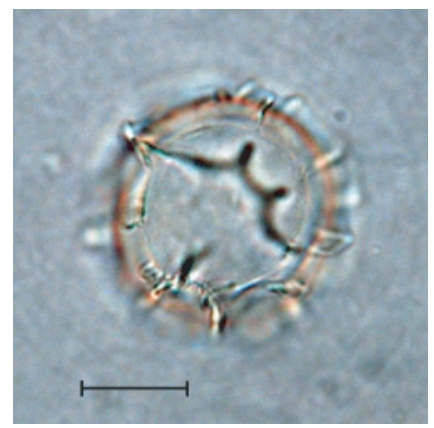

23

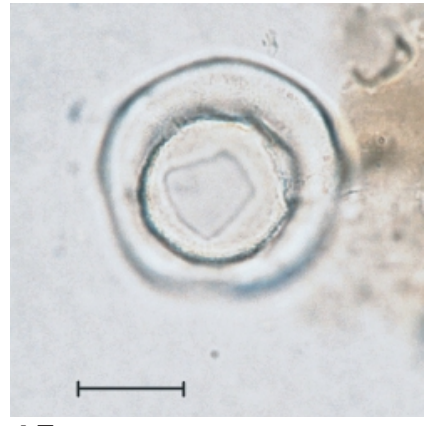

15

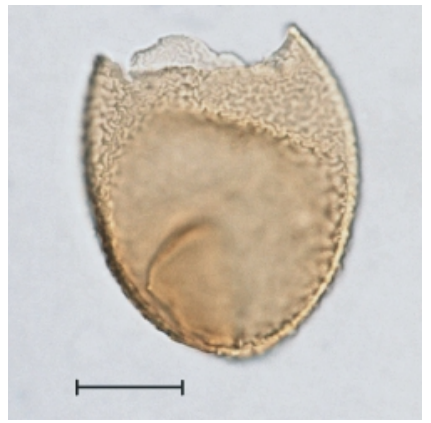

18

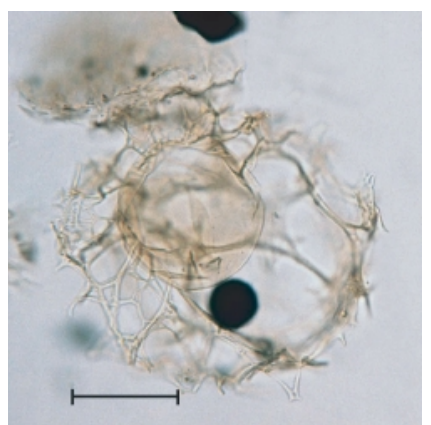

21

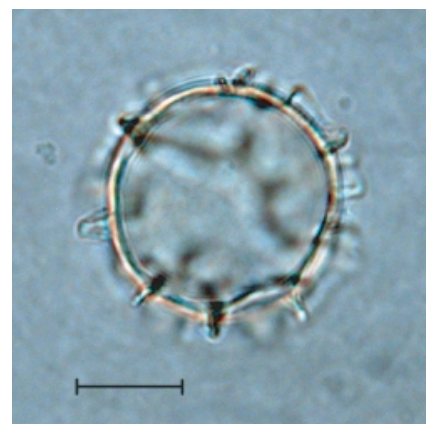

24 
H. BRINKHUIS ET AL.

LATE Eocene-QuATERnARy Dinoflagellate Cysts

Plate P1 (continued). 25-27. Cerebrocysta poulsenii (Sample 189-1168A-20X-2, 60-62 cm); 1, O48-3 (scale bar $=\sim 15 \mu \mathrm{m})$. 28-31. Cerebrocysta spp. (Sample 189-1168A-20X-2, 60-62 cm); 1, J49-4 (scale bar $=\sim 15 \mu \mathrm{m})$. 32, 33. Cerebrocysta sp. A (Sample 189-1168A-33X-3, 60-62 cm); 2, H35-4 (scale bar $=\sim 30 \mu \mathrm{m})$. 34. Chiropteridium spp. (Sample 189-1168A-50X-2, 60-62 cm); 1, S26-1. 35, 36. Cleistosphaeridium spp. (Sample 1891168A-64X-5, 60-62 cm); 1, J51-3. (Continued on next page.)

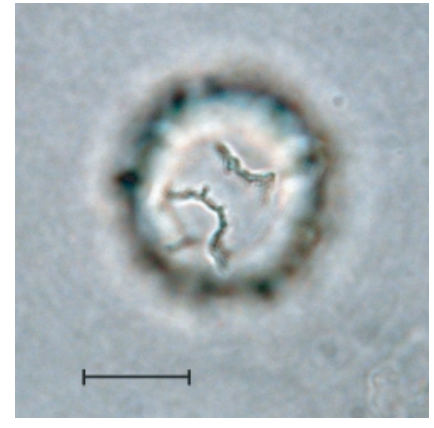

25

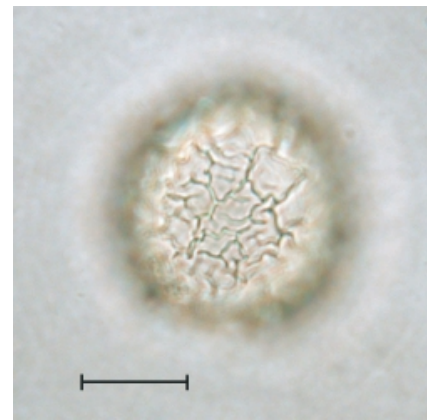

28

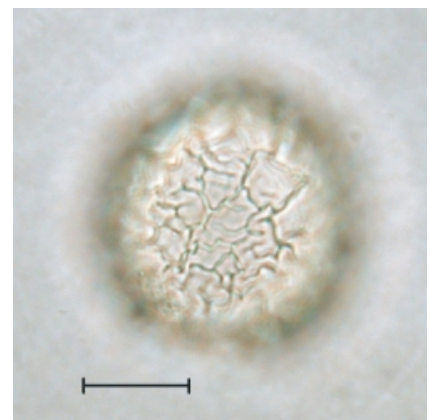

31

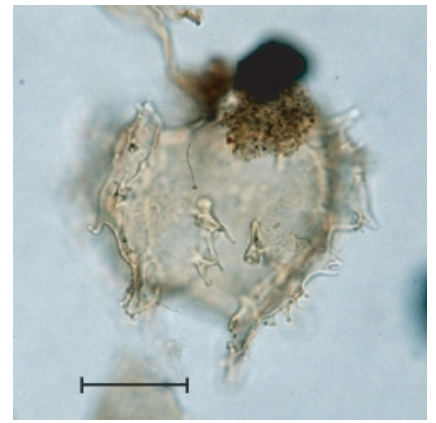

34

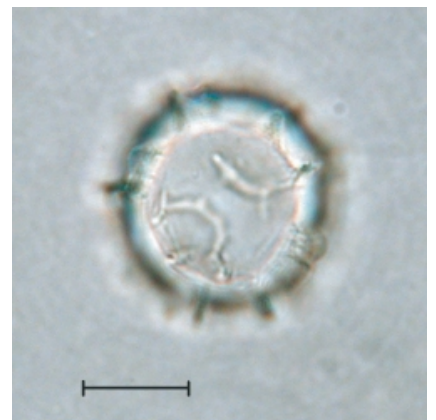

26

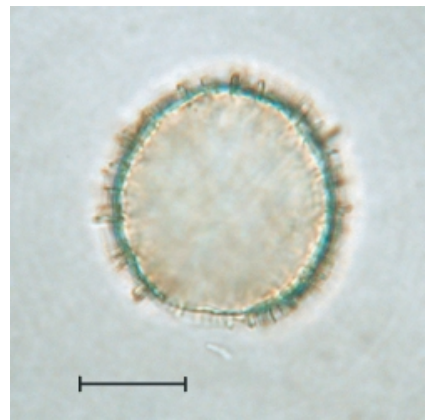

29

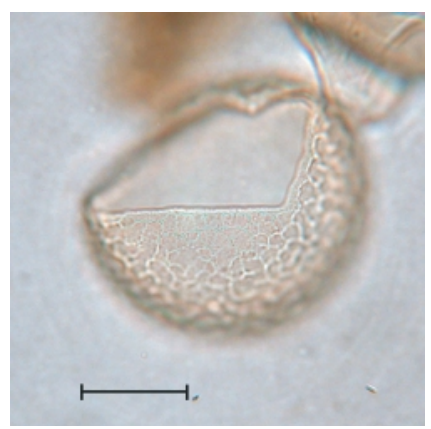

32

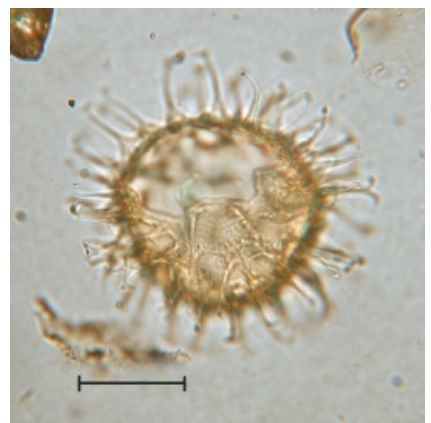

35

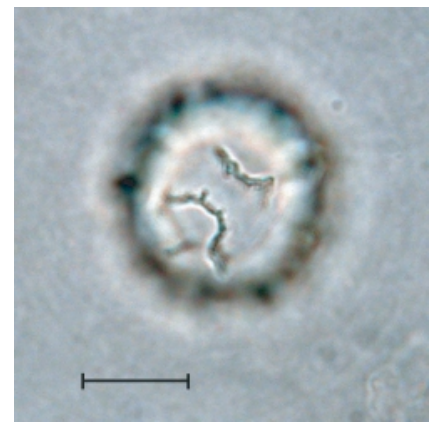

27

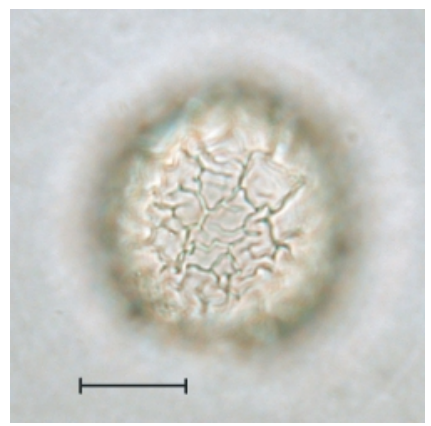

30

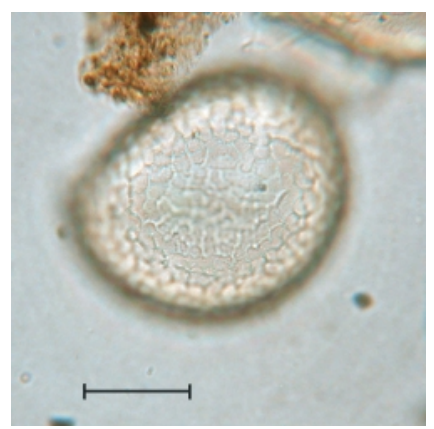

33

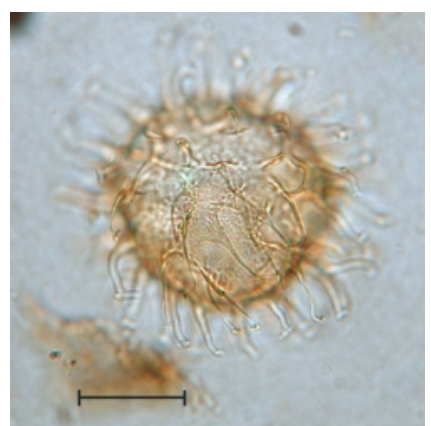

36 
H. BRINKHUIS ET AL.

LATE Eocene-QuATERnARy Dinoflagellate Cysts

Plate P1 (continued). 37, 38. Cooksonidium capricornum (Sample 189-1168A-86X-5, 60-62 cm); 1, S49-4. 39. Deflandrea convexa (Sample 189-1168A-83X-4, 60-62 cm); 2, L28-2. 40. Diphyes ficusoides (Sample 1891168A-84X-3, 60-62 cm); 2, D27. 41, 42. Distatodinium biffii (Sample 189-1168A-54X-2, 60-62 cm); 2, M211 (scale bar $=\sim 35 \mu \mathrm{m})$. 43-45. Ectosphaeropsis burdigalensis (Sample 189-1168A-50X-2, 60-62 cm) (scale bar = $30 \mu \mathrm{m}$ ); (43) 1, N13-4; (44) 1, K30-3; (45) 1, L30-2. 46, 47. Edwardsiella sexispinosum (Sample 189-1168A38X-2, 60-62 cm); 1, U30-1. 48. Emmetrocysta urnaformis (Sample 189-1168A-88X-1, 60-62 cm); 1, T27. (Continued on next page.)

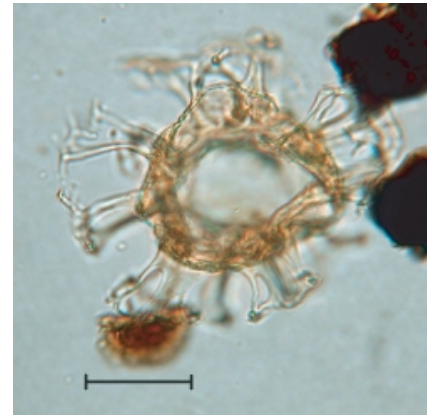

37

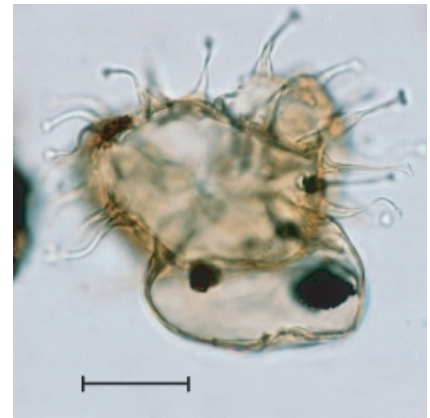

40

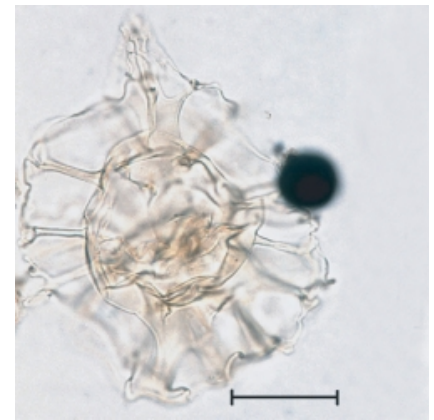

43

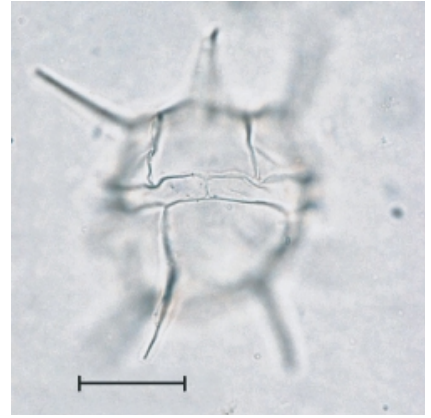

46

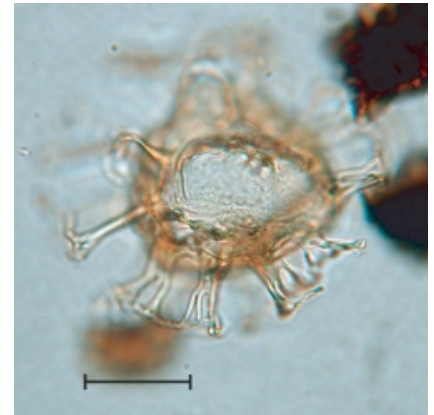

38

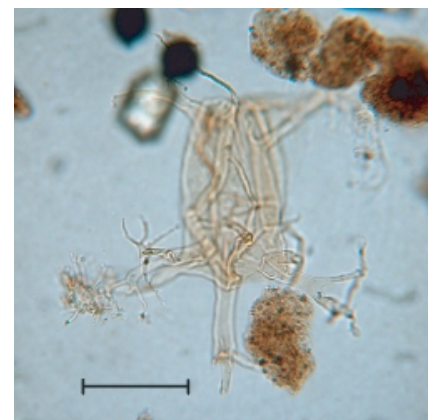

41

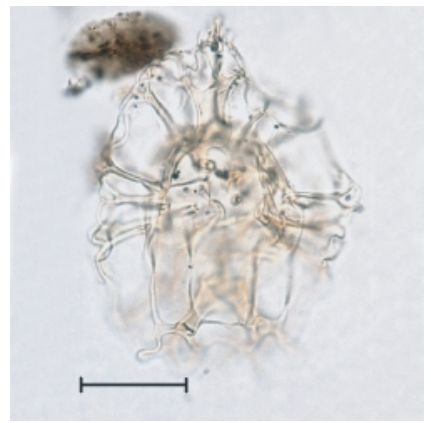

44

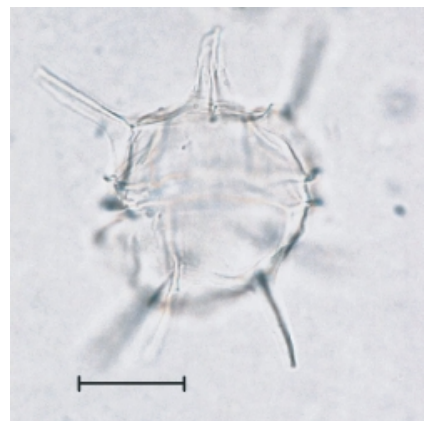

47

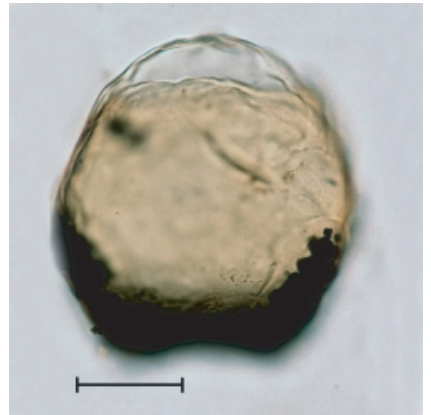

39

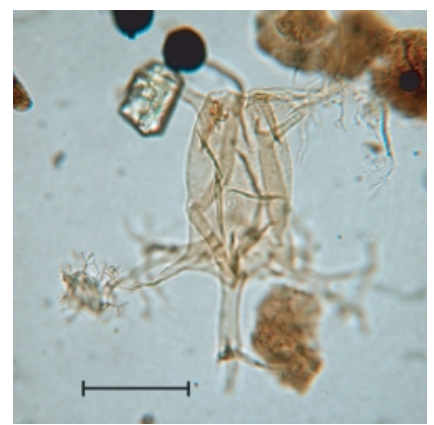

42

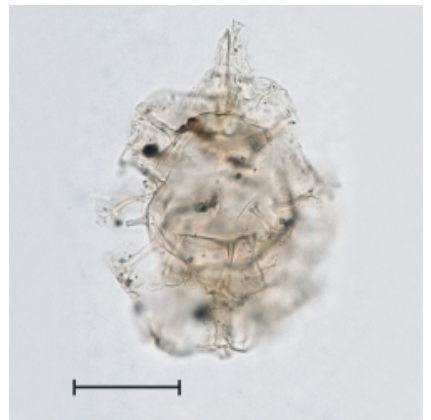

45

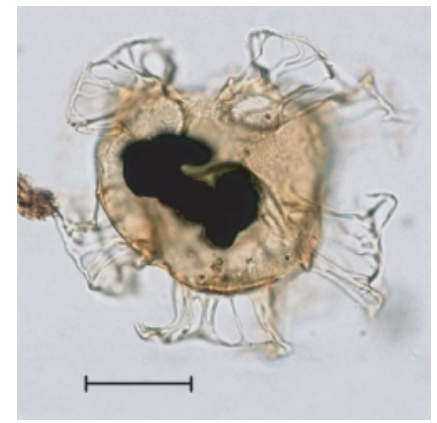

48 
H. BRINKHUIS ET AL.

LATE Eocene-QuATERnARy Dinoflagellate Cysts

Plate P1 (continued). 49. Eurydinium sp. (Sample 189-1168A-82X-1, 60-62 cm); 1, P28-1. 50, 51. Gelatia inflata (Sample 189-1168A-64X-5, 60-62 cm); 1, P63-3 (scale bar $=\sim 10 \mu \mathrm{m}$ ). 52-54. Glaphyrocysta intricata (Sample 189-1168A-57X-7, 60-62 cm); 1, S22-4. 55-60. Mendicodinium. sp. A Wrenn and Kokinos, 1986 (Sample 189-1168A-25X-4, 60-62 cm); (55-57) 1, R36-3; (58-60) 1, T51-4. (Continued on next page.)

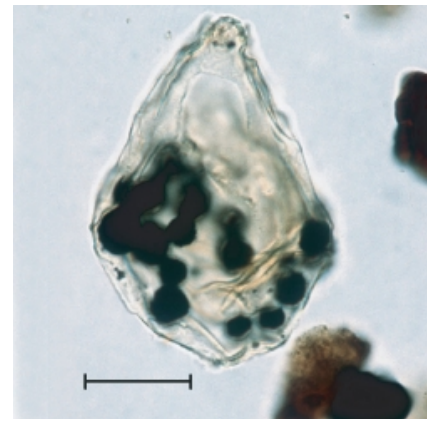

49

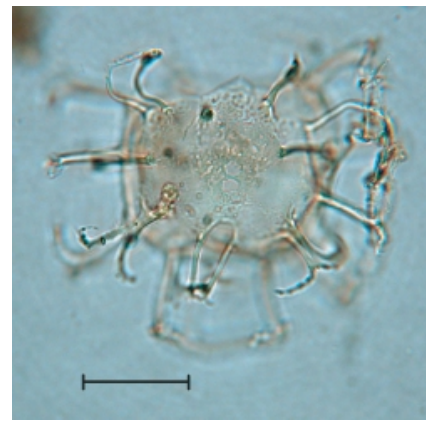

52

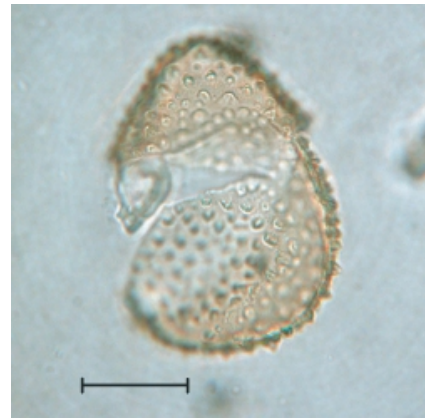

55

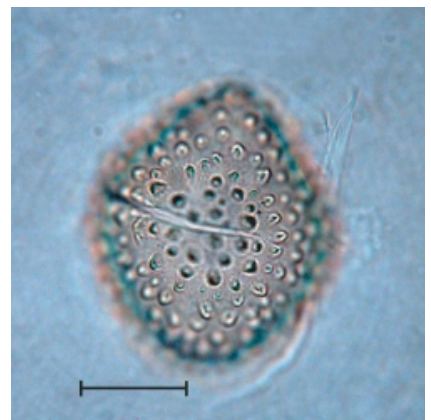

58

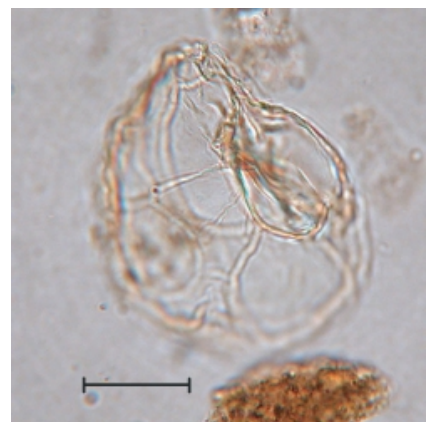

50

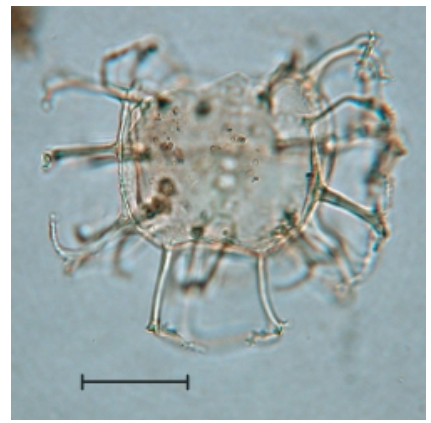

53

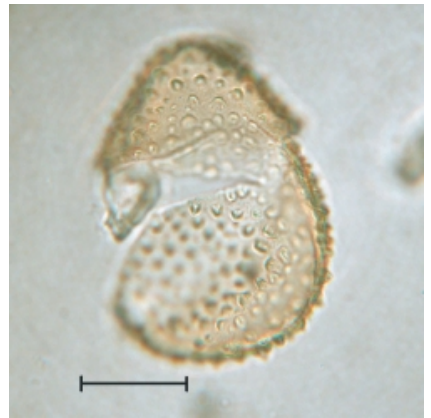

56

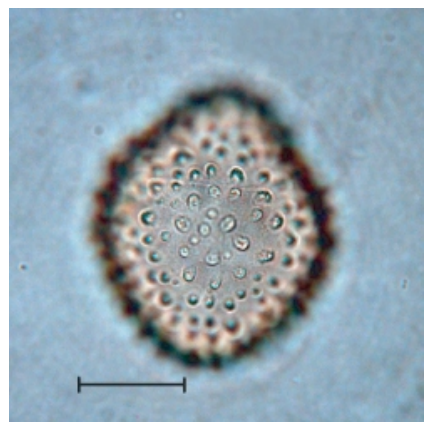

59

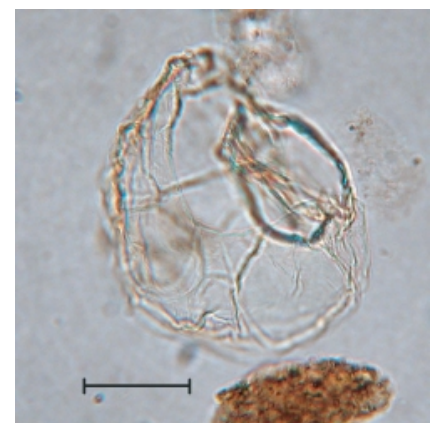

51

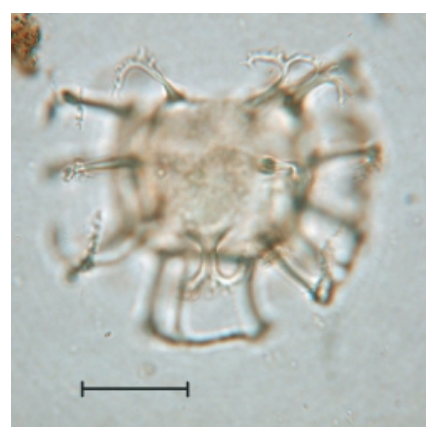

54

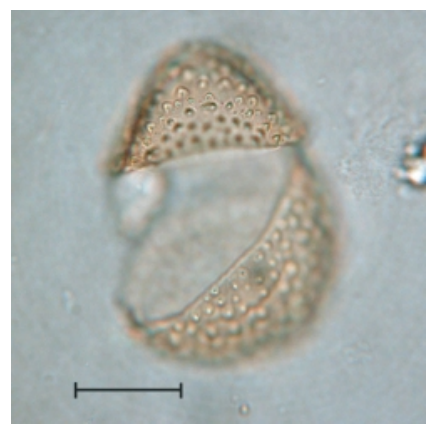

57

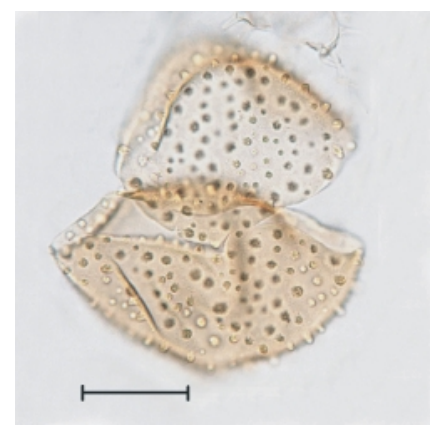

60 
H. BRINKHUIS ET AL.

LATE Eocene-QuATERnARy Dinoflagellate Cysts

Plate P1 (continued). 61-63. Hystrichokolpoma pusilla (Sample 189-1168A-65X-3, 60-62 cm); 1, O57-4. 64, 65. Hystrichokolpoma rigaudiae (Sample 189-1168A-42X-4, 60-62 cm); 2, G35. 66, 67. Hystrichokolpoma sp. A (Samples 189-1168A-66X-1, 60-62 cm); 1, Q15-3. 68. Hystrichosphaeropsis obscura (Sample 189-1168A40X-6, 60-62 cm); 1, S19-4. 69, 70. Impagidinium aculeatum (Sample 189-1168A-6H-3, 60-62 cm); 1, W262 (scale bar $=\sim 10 \mu \mathrm{m}) .71,72$. Impagidinium paradoxum (Sample 189-1168A-3H-3, 60-62 cm); 2, V20-4 (scale bar $=\sim 10 \mu \mathrm{m})$. (Continued on next page.)

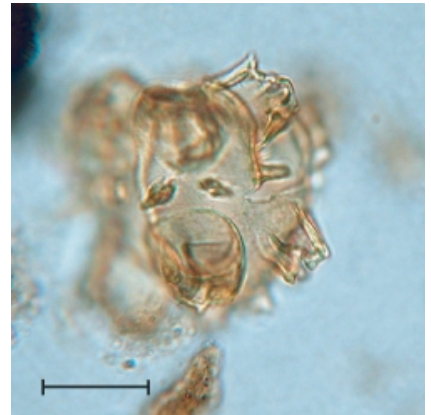

61

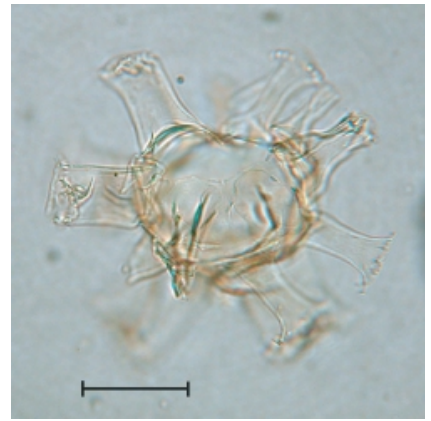

64

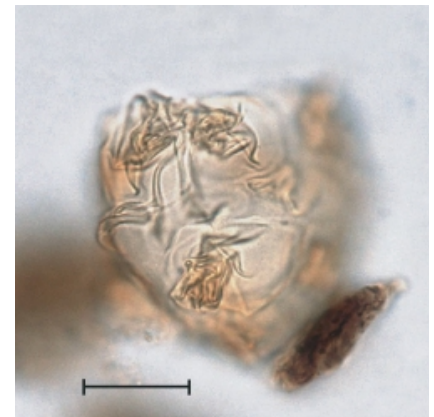

67

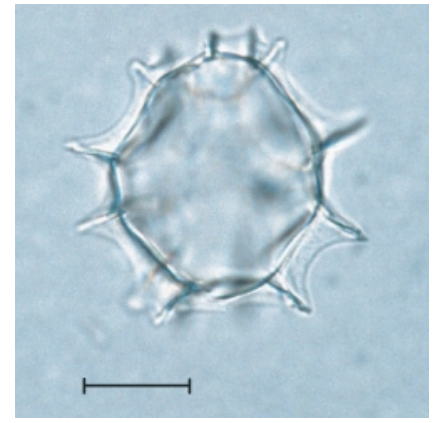

70

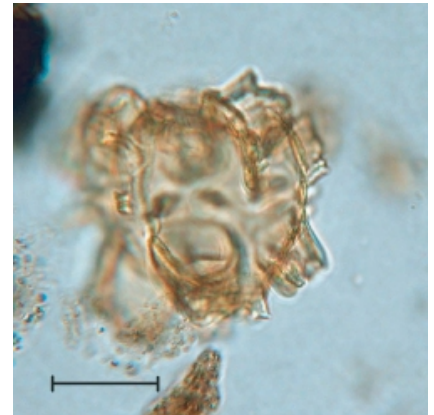

62

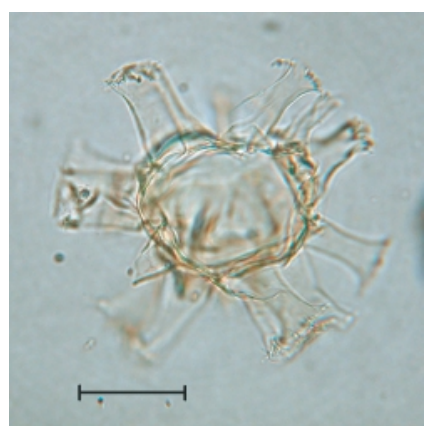

65

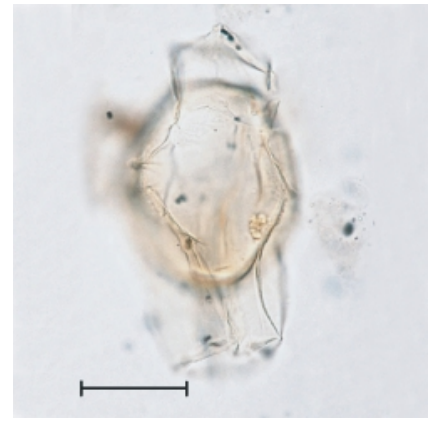

68

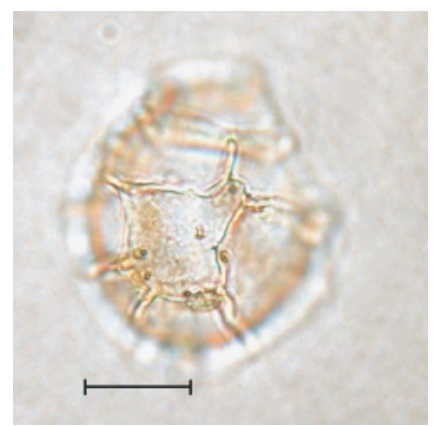

71

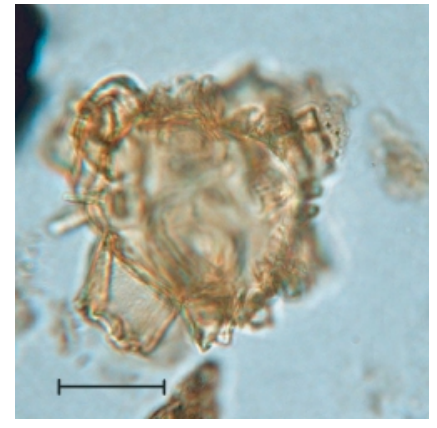

63

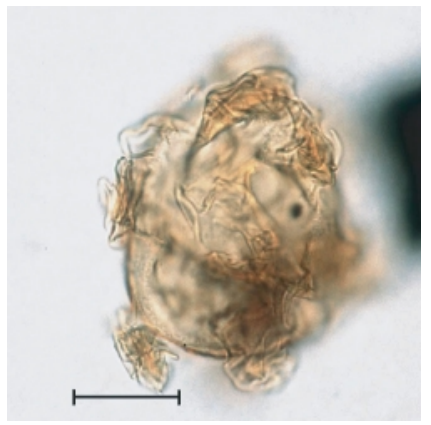

66

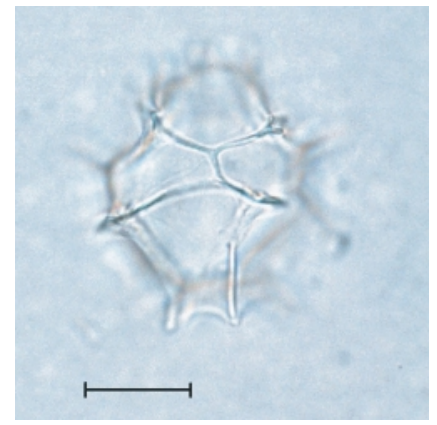

69

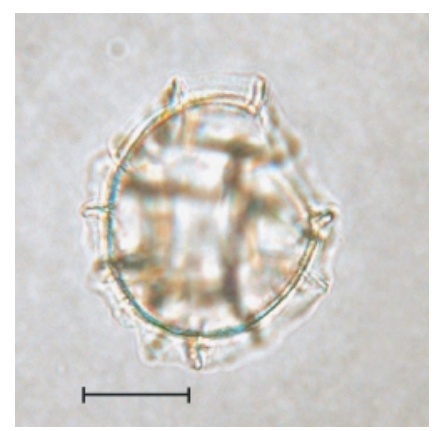

72 
H. BRINKHUIS ET AL.

LATE Eocene-QuATERnARy Dinoflagellate Cysts

Plate P1 (continued). 73, 74. Impagidinium paradoxum (Sample 189-1168A-3H-3, 60-62 cm); 2, V20-4 (scale bar $=\sim 10 \mu \mathrm{m})$. 75, 76. Impagidinium patulum (Sample 189-1168A-20X-2, 60-62 cm); 1, F38-3. 77. Invertocysta tabulata (Sample 189-1168A-10H-7, 60-62 cm); 1, R32. 78, 79. Labyrinthodinium truncatum (Sample 189-1168A-23X-5, 60-62 cm); 2, S23-3 (scale bar $=\sim 10 \mu \mathrm{m}$ ). 80. Melitasphaeridium choanophorum (Sample 189-1168A-13X-1, 60-62 cm); 2, M26. 81-84. Membranilarnacia? picena (Sample 189-1168A-65X-3, 60$62 \mathrm{~cm}$ ); 1, R57-2. (Continued on next page.)

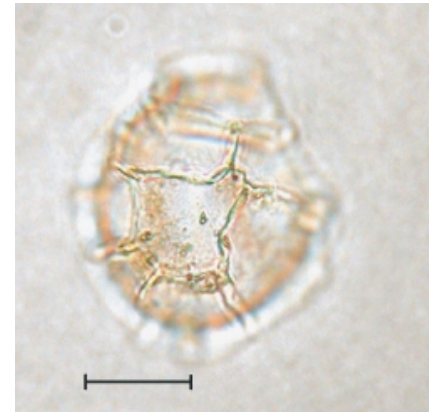

73

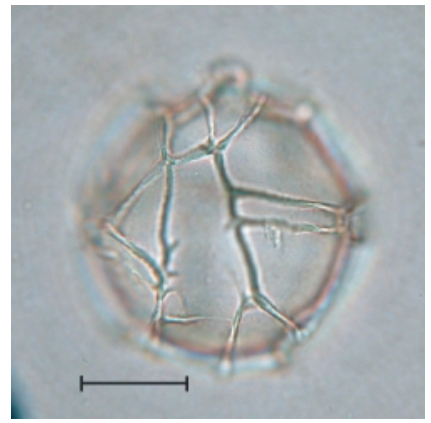

76

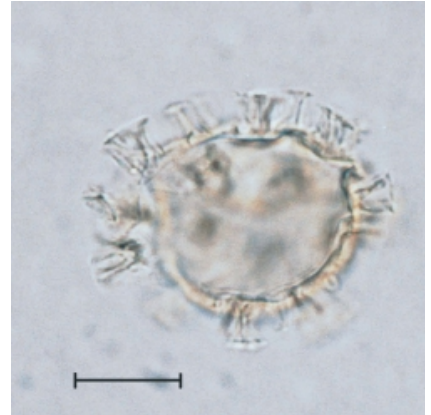

79

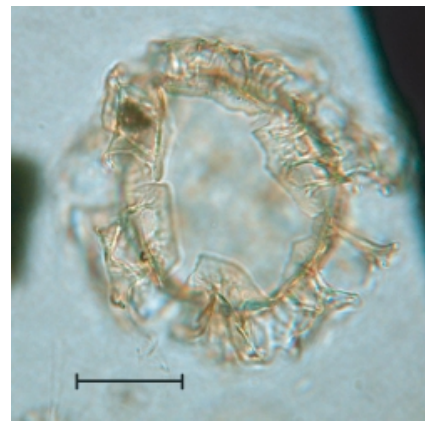

82

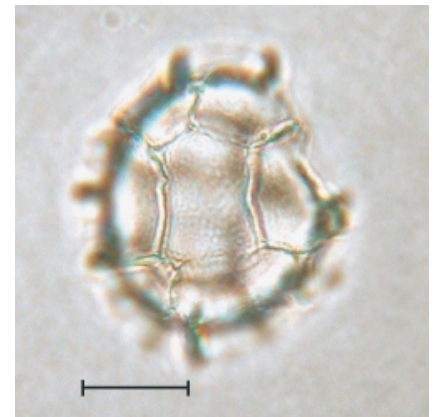

74

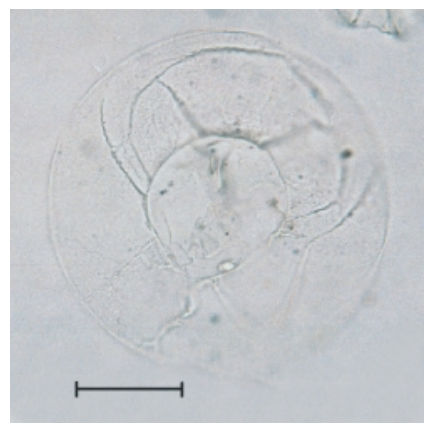

77

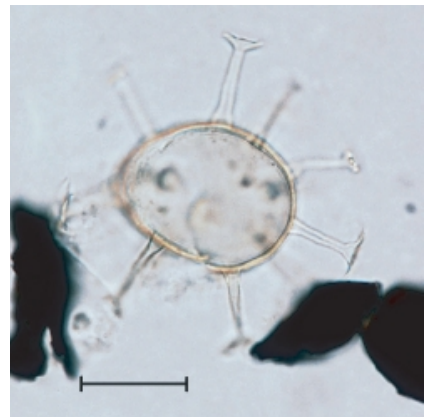

80

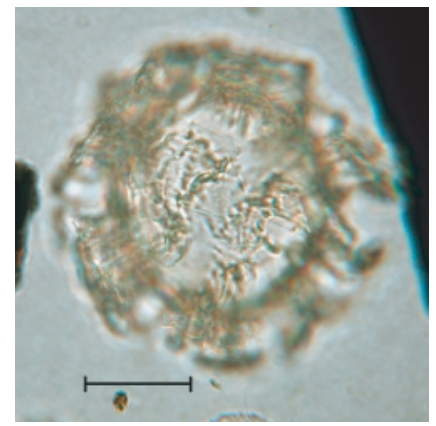

83

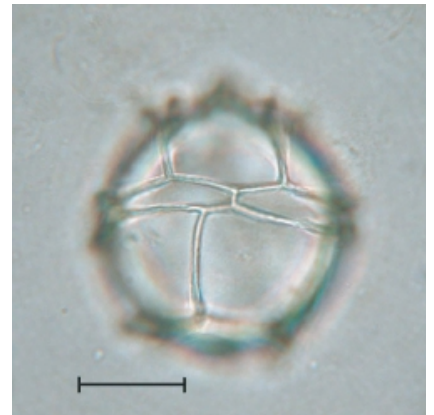

75

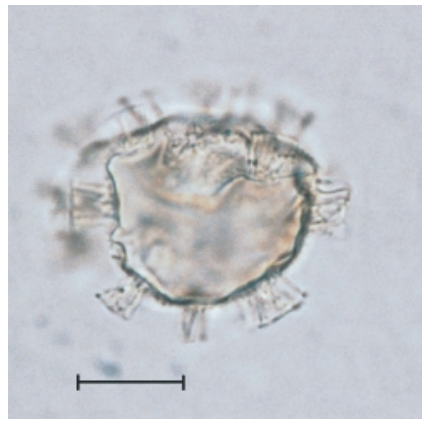

78

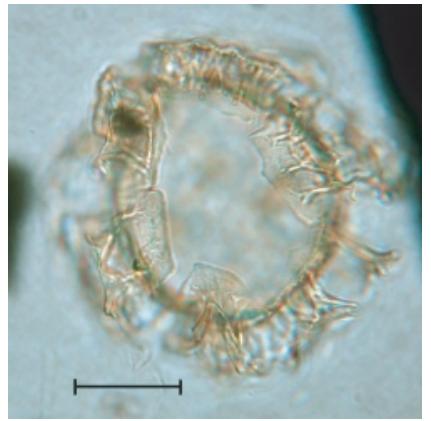

81

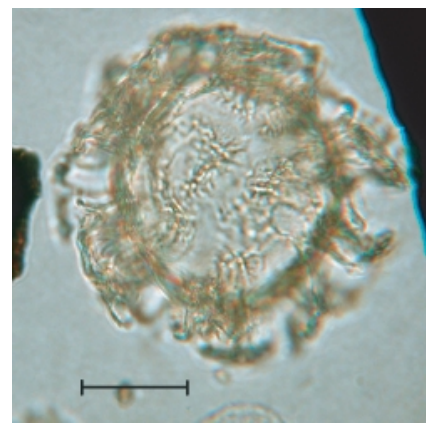

84 
H. BRINKHUIS ET AL.

LATE Eocene-QuATERnARy Dinoflagellate Cysts

Plate P1 (continued). 85-87. Membranilarnacia? picena (Sample 189-1168A-41X-3, 60-62 cm); 1, K35-3. 88-90. Membranilarnacia sp. (Sample 189-1168A-84X-6, 60-62 cm); 1, U32-3 (scale bar = 10 $\mu \mathrm{m}$ ). 91-93. Nematosphaeropsis labyrinthus (Sample 189-1168A-20X-2, 60-62 cm); 1, H47-4 (scale bar = 10 $\mu \mathrm{m}$ ). 94. Octodinium askiniae (Sample 189-1168A-93X-6, 60-62 cm); 1, R25-2. 95, 96. Operculodinium piaseckii (Sample 189-1168A-25X-4, 60-62 cm); 1, J40-3 (scale bar = 15 $\mu \mathrm{m}$ ). (Continued on next page.)

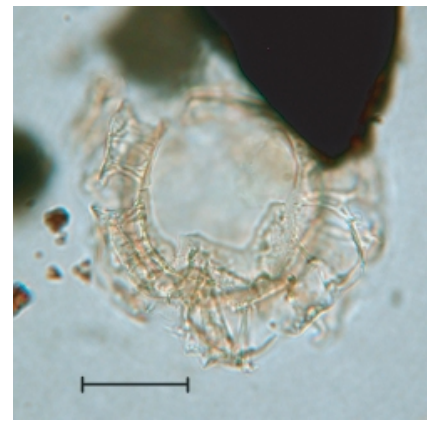

85

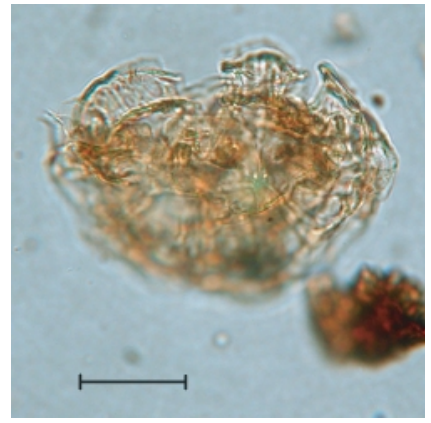

88

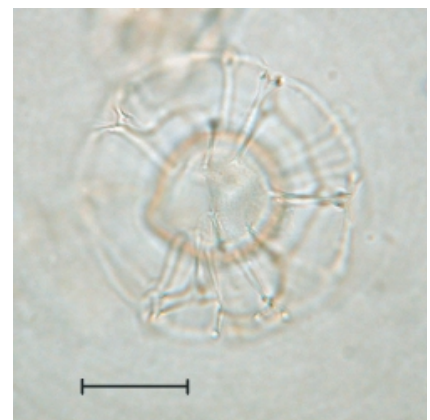

91

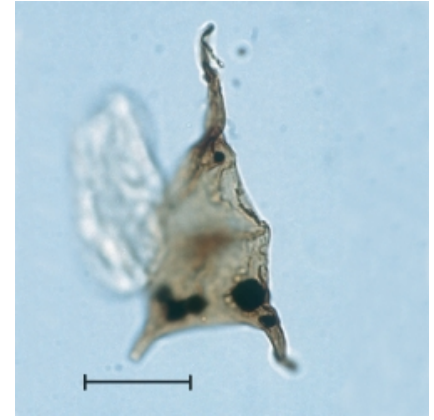

94

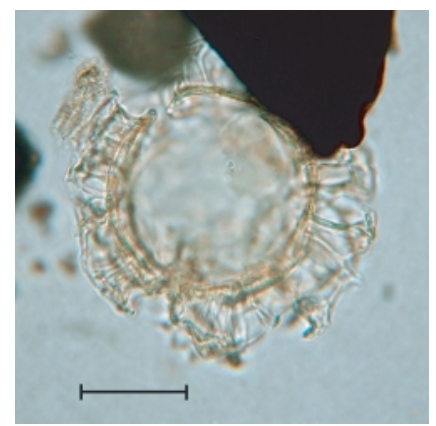

86

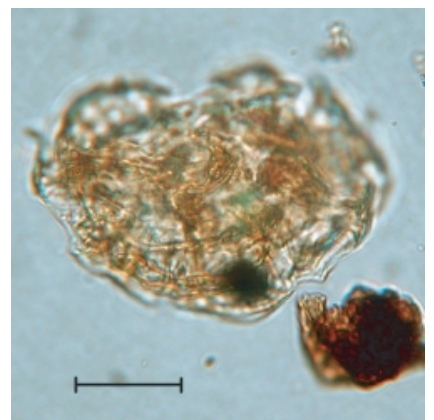

89

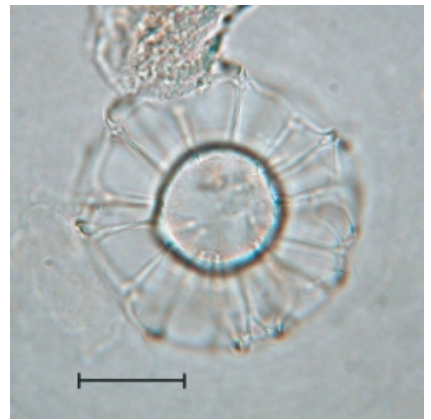

92

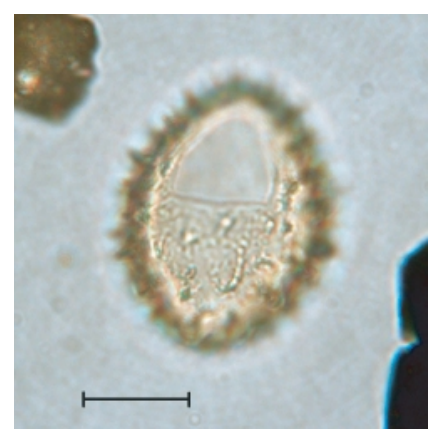

95

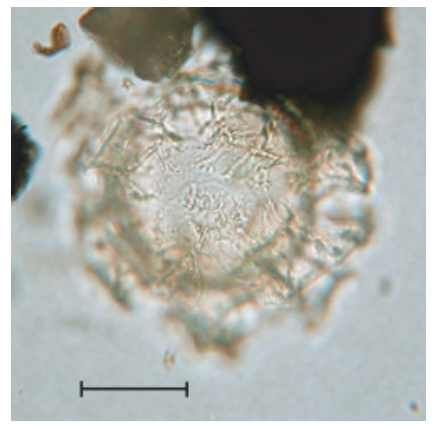

87

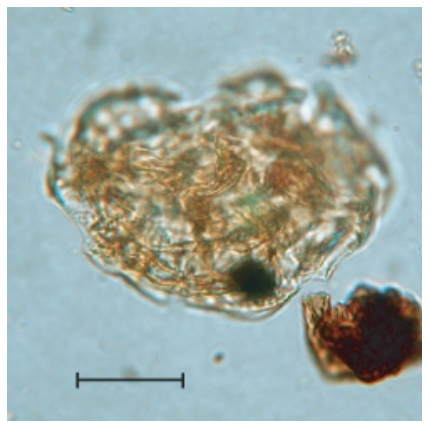

90

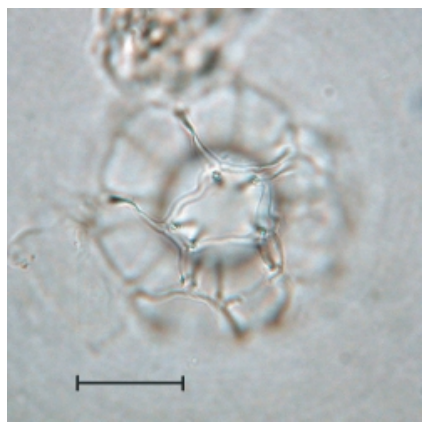

93

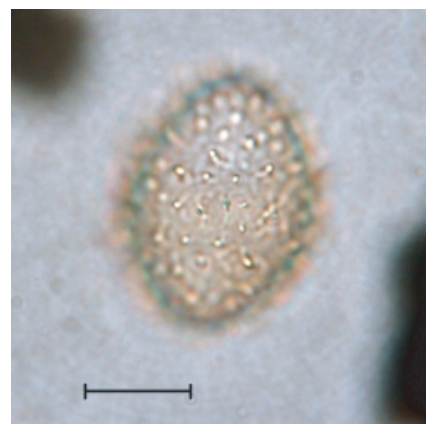

96 
H. BRINKHUIS ET AL.

Plate P1 (continued). 97-99. Operculodinium janduchenei (Sample 189-1168A-10H-7, 60-62 cm); 1, T22-4 (scale bar $=\sim 15 \mu \mathrm{m}$ ). 100-102. Cyst of Pentapharsodinium dalei and Algidasphaeridium minutum cezare (Sample 189-1168A-3H-3, 60-62 cm); 2, T20-1. 103-106. Pentadinium laticinctum (Sample 189-1168A-33X-3, 60$62 \mathrm{~cm}$ ); 1, T51-1 (scale bar $=\sim 15 \mu \mathrm{m}) .107,108$. Phthanoperidinium filigranum (Sample 189-1168A-78X-7, $60-62 \mathrm{~cm}) ; 2$, T30-2 (scale bar $=\sim 10 \mu \mathrm{m})$. (Continued on next page.)

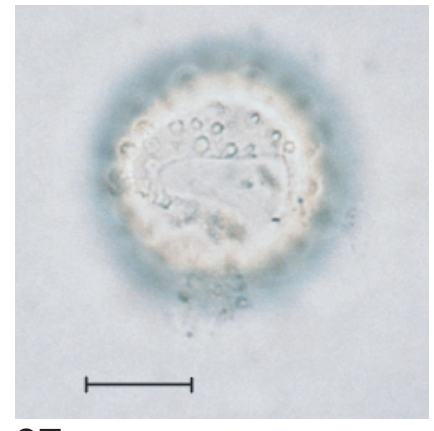

97

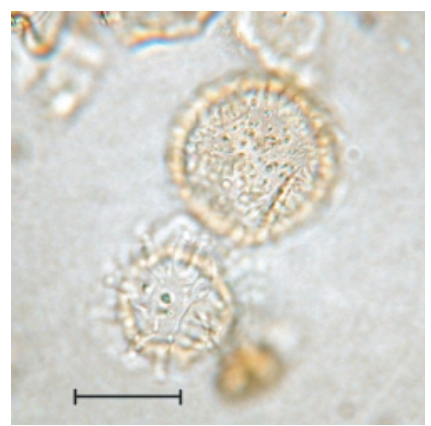

100

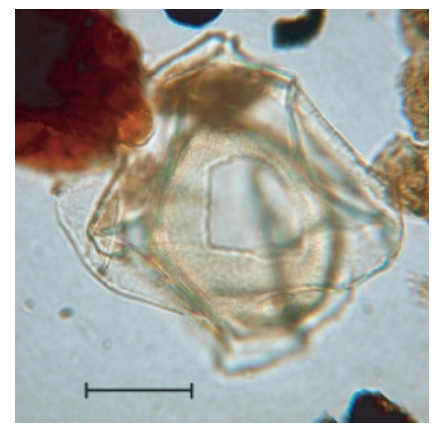

103

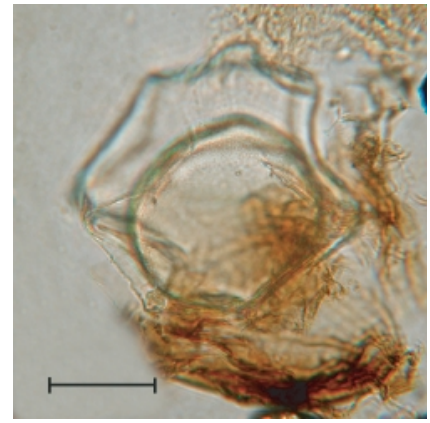

106

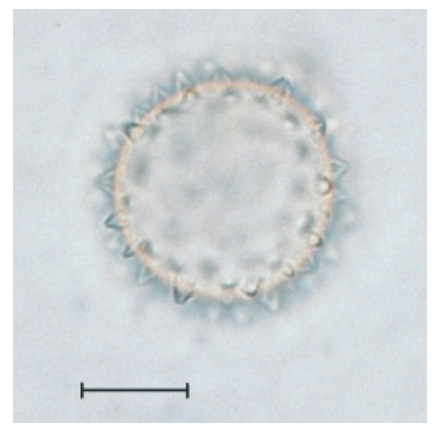

98

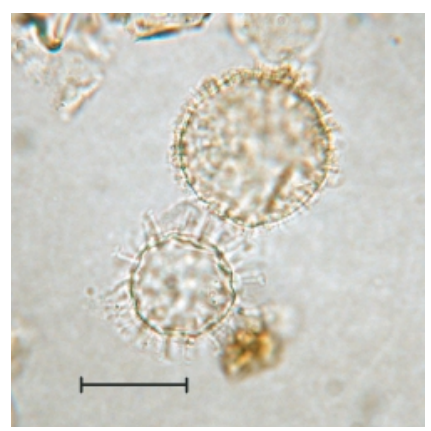

101

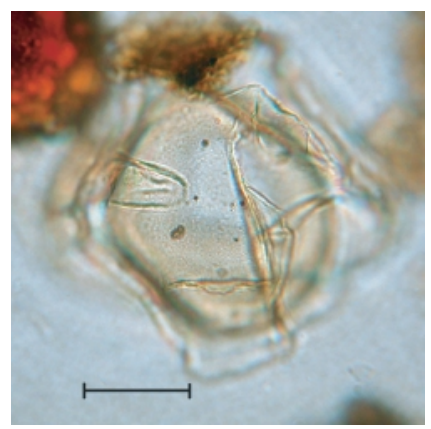

104

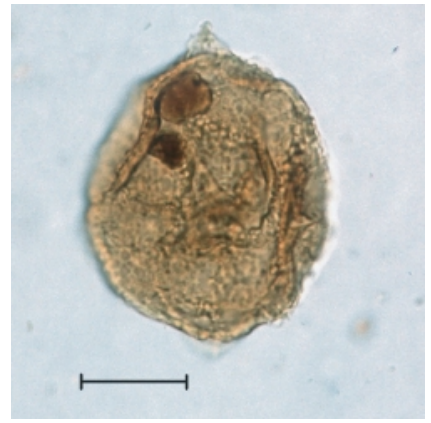

107

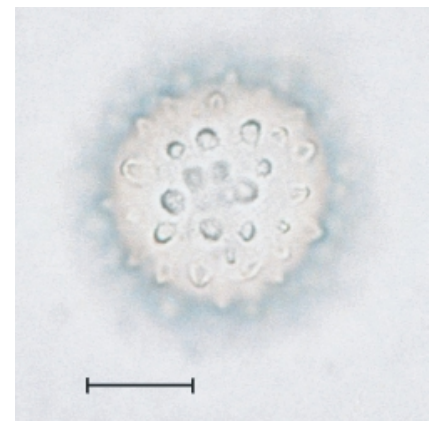

99

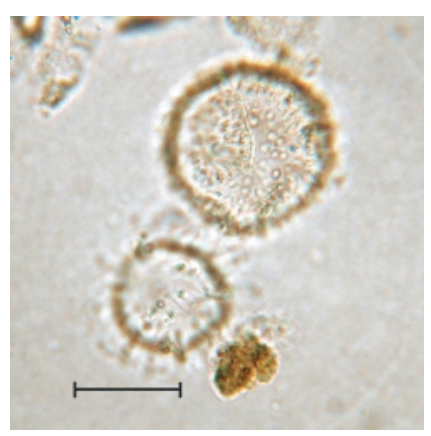

102

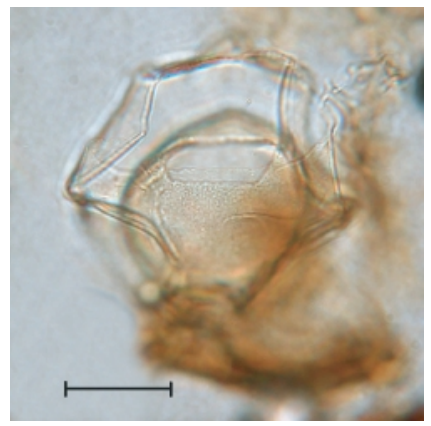

105

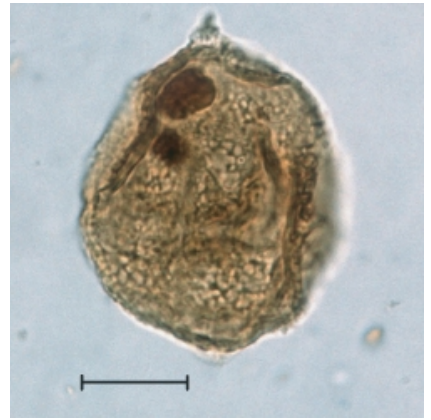

108 
H. BrinkHUIS ET AL.

LATE Eocene-QuATERnARy Dinoflagellate Cysts

Plate P1 (continued). 109-111. Samlandia chlamydophora (Sample 189-1168A-79X-6, 60-62 cm); 1, J39. 112, 113. Schematophora speciosa (Sample 189-1168A-94X-3, 60-62 cm); 1, T31-2 (scale bar $=\sim 10 \mu \mathrm{m})$. 114, 115. Spiniferites cf. mirabilis (Sample 189-1168A-3H-3, 60-62 cm); 2, U23-4. 116, 117. Stoveracysta cf. conerae (Sample 189-1168A-38X-4, 60-62 cm); 1, Q27-1 (scale bar = 15 $\mu \mathrm{m}) .118,119$. Stoveracysta ornata $($ Sample 189-1168A-79X-6, 60-62 cm); 1, J35-4 (scale bar = 15 $\mu \mathrm{m})$. 120. Stoveracysta ornata (Sample 189-1168A79X-6, 60-62 cm); 1, Q32-3 (scale bar = 15 $\mu \mathrm{m}$ ). (Continued on next page.)

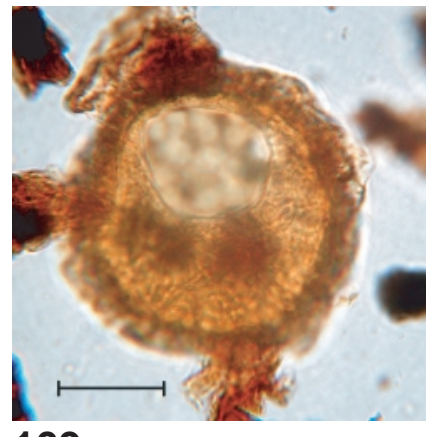

109

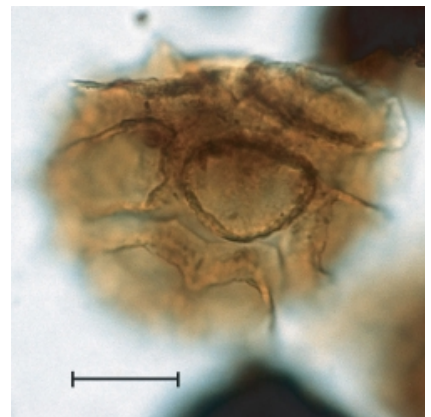

112

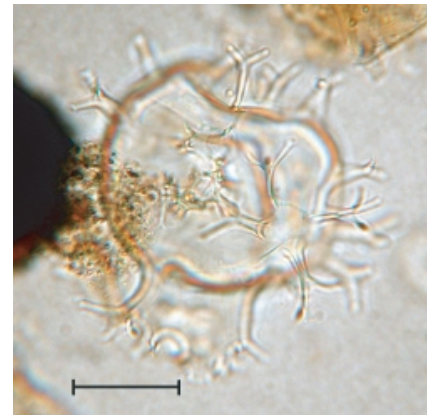

115

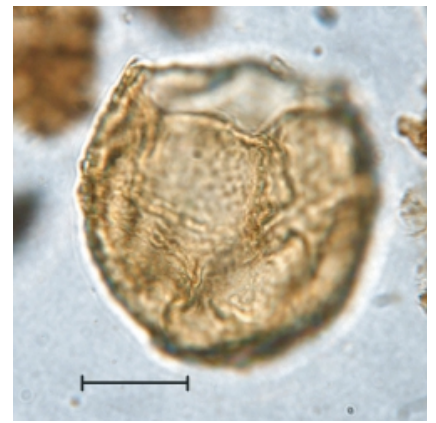

118

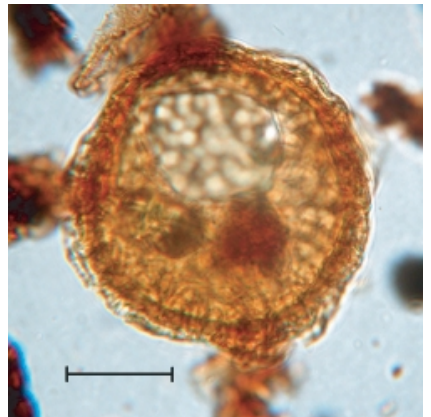

110

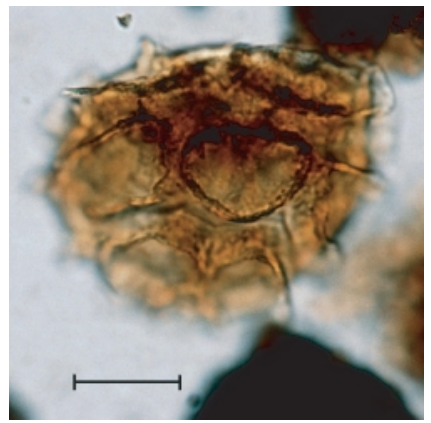

113

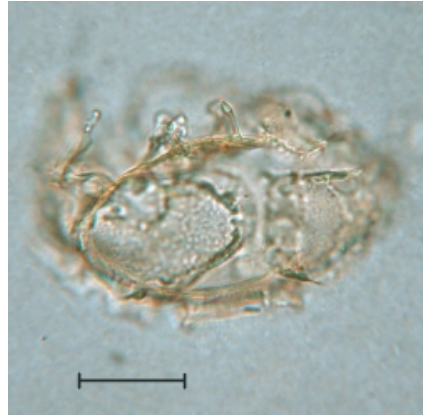

116

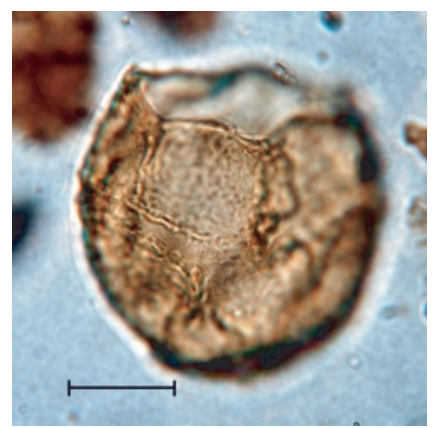

119

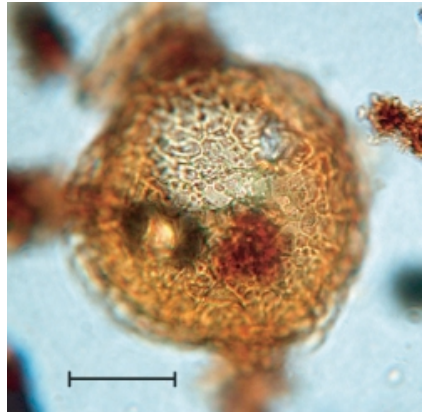

111

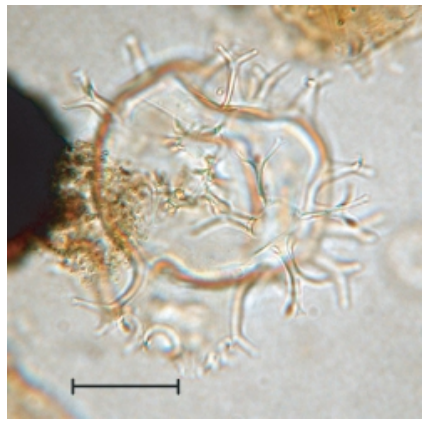

114

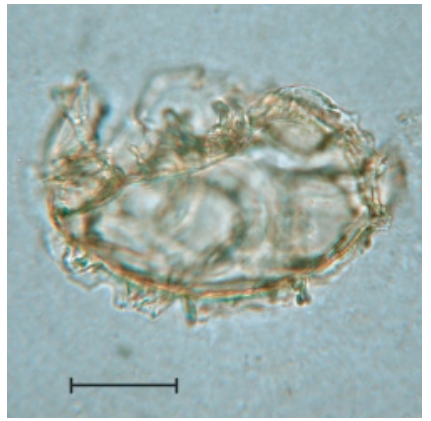

117

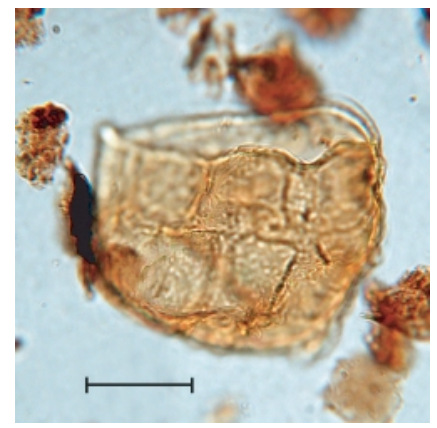

120 
Plate P1 (continued). 121. Stoveracysta ornata $($ Sample 189-1168A-79X-6, 60-62 cm); 1, Q32-3 $($ scale bar = $\sim 15 \mu \mathrm{m}) .122,123$. Stoveracysta kakanuiensis (Sample 189-1168A-79X-5, 60-62 cm); 1, M34-1 (scale bar = $\sim 15 \mu \mathrm{m}$ ). 124. Stoveracysta ornata (Sample 189-1168A-79X-5, 60-62 cm); 1, V22-3 (scale bar = 15 $\mu \mathrm{m}) .125-$ 127. Svalbardella sp. (Sample 189-1168A-58X-3, 60-62 cm); (125) 2, H20-1; (126, 127) 1, V57-3. 128. Apteodinium australiense (Sample 189-1168A-45X-3, 59-61 cm); scanning electron microscope (SEM). 129. Cleistosphaeridium sp. and Eocladopyxis sp. (Sample 189-1168A-45X-3, 59-61 cm); SEM. 130. Cordosphaeridium minimum (Sample 189-1168A-45X-3, 59-61 cm); SEM. 131. Dapsilidinium sp. (Sample 189-1168A-45X-3, 59-61 cm); SEM. 132. Eocladopyxis sp. (Sample 189-1168A-45X-3, 59-61 cm); SEM. (Continued on next page.)

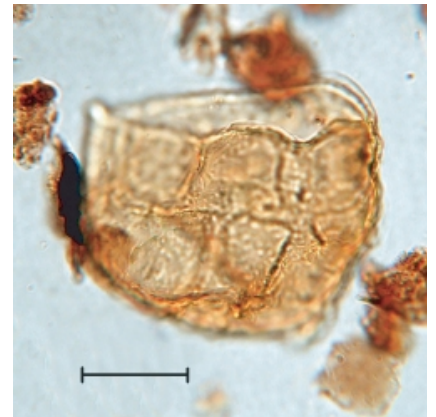

121

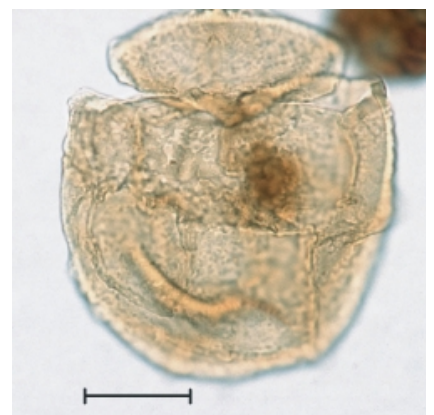

124

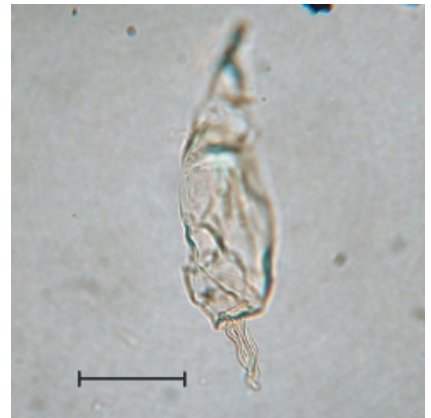

127

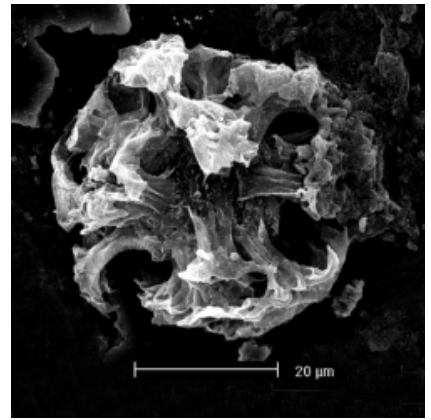

130

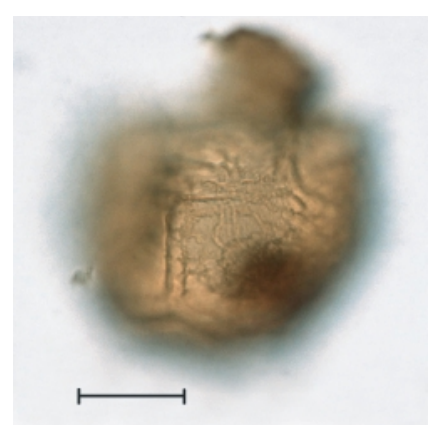

122

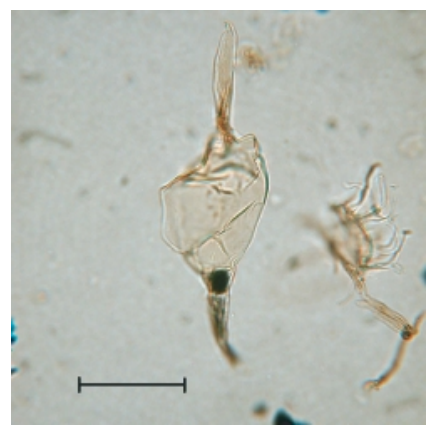

125

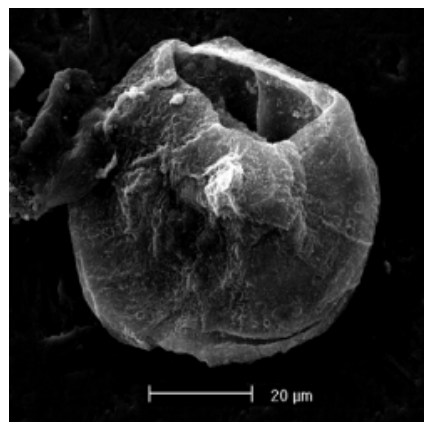

128

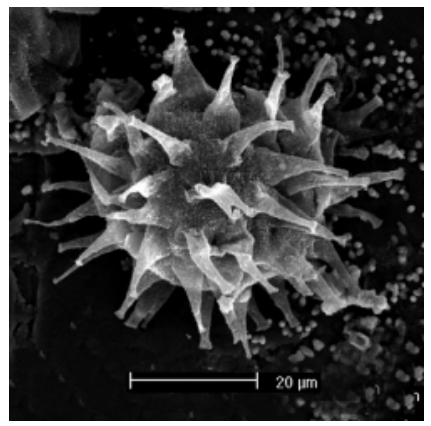

131

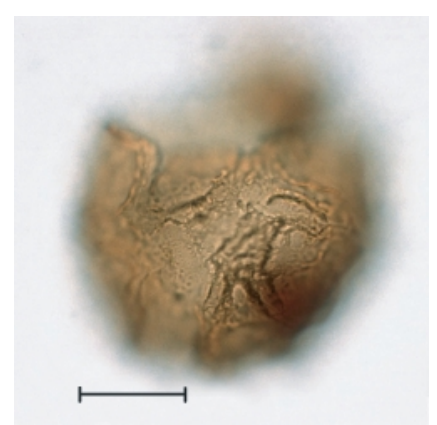

123

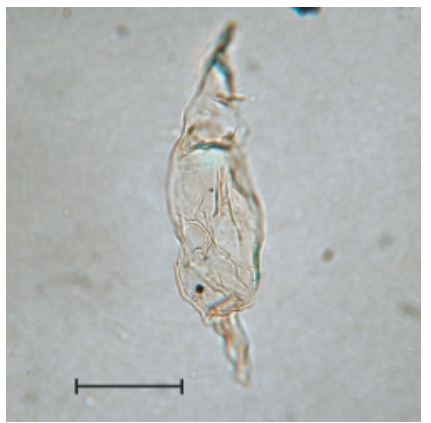

126

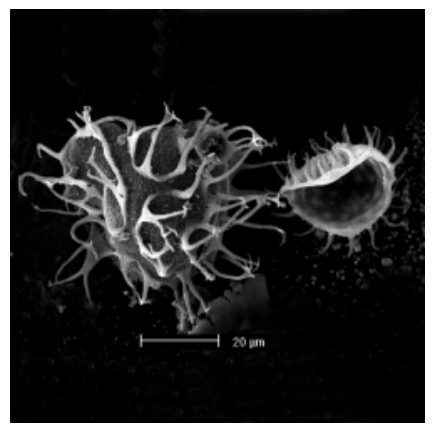

129

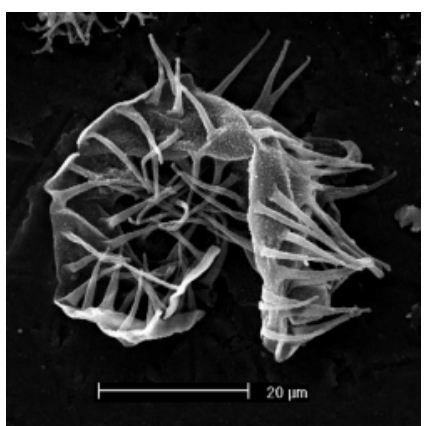

132 


\section{H. BRINKHUIS ET AL.}

Plate P1 (continued). 133. Hystrichokolpoma rigaudiae (Sample 189-1168A-45X-3, 59-61 cm); SEM. 134. Impagidinium aculeatum (Sample 189-1168A-45X-3, 59-61 cm); SEM. 135. Impagidinium paradoxum (Sample 189-1168A-45X-3, 59-61 cm); SEM. 136. Nematosphaeropsis labyrinthea (Sample 189-1168A-45X-3, 59-61 $\mathrm{cm}$ ); SEM. 137. Operculodinium sp., (Sample 189-1168A-45X-3, 59-61 cm); SEM. 138. Operculodinium centrocarpum (Sample 189-1168A-45X-3, 59-61 cm); SEM. 139. Reticulatosphaera actinocoronata (Sample 1891168A-45X-3, 59-61 cm); SEM. 140, 142-144. Skolochorate acritarchs; SEM; (140) Sample 189-1168A-45X3, 59-61 cm; (142-144) Sample 189-1168A-42X-4, 60-62 cm. 141. Skolochorate acritarchs and framboidal pyrite spheres (Sample 189-1168A-38X-2, 60-62 cm); SEM. (Continued on next page.)

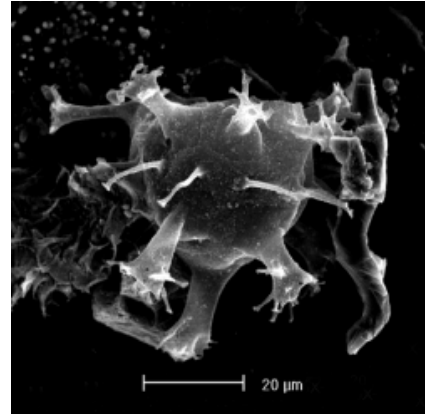

133

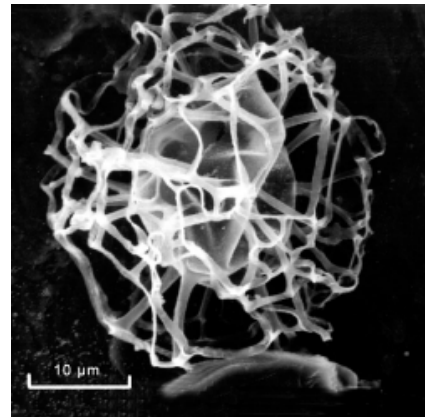

136

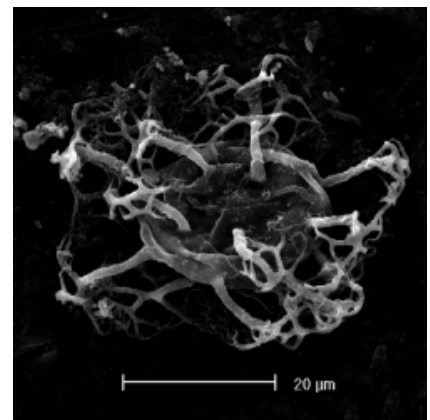

139

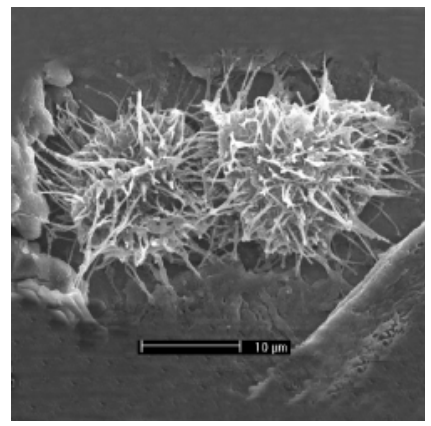

142

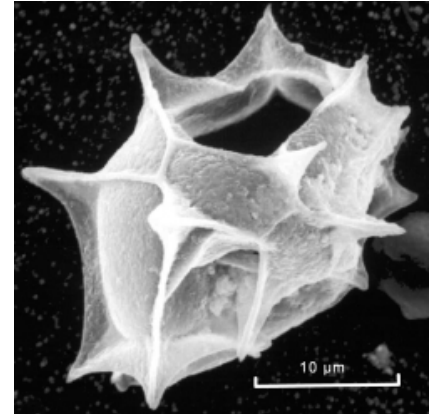

134

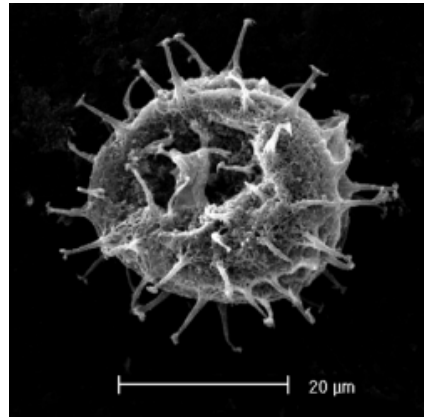

137

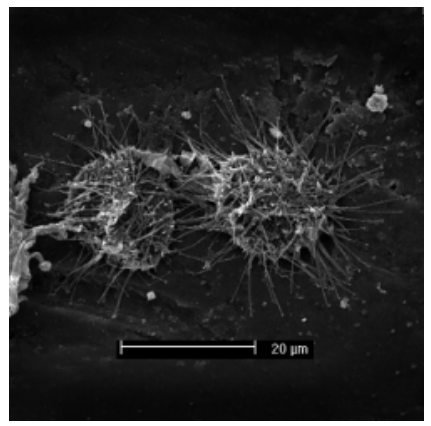

140

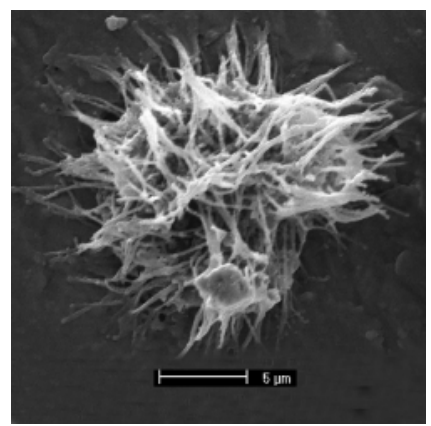

143

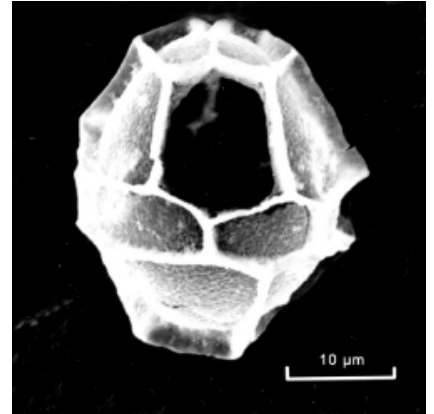

135

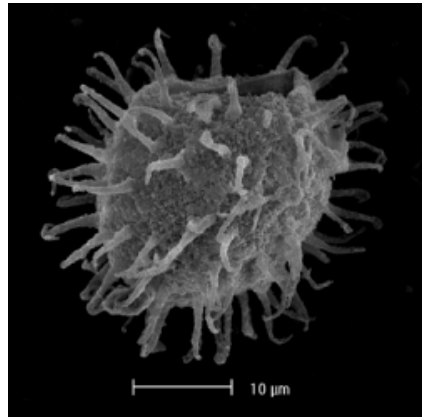

138

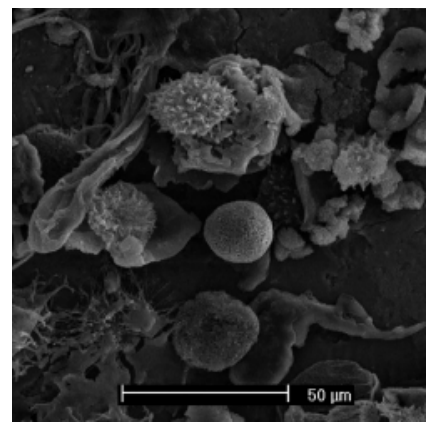

141

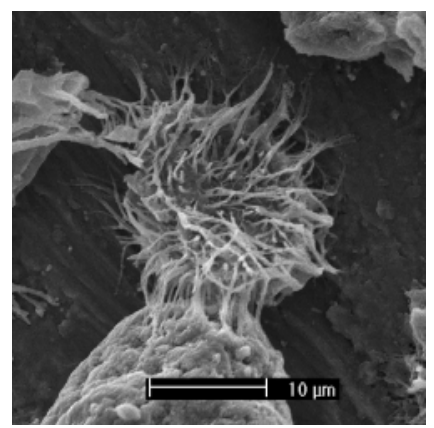

144 
H. BRINKHUIS ET AL.

LATE Eocene-QuATERnARy Dinoflagellate Cysts

Plate P1 (continued). 145-151. Skolochorate acritarchs; SEM; (145) Sample 189-1168A-42X-4, 60-62 cm; (146-151) Sample 189-1168A-38X-2, 60-62 cm.

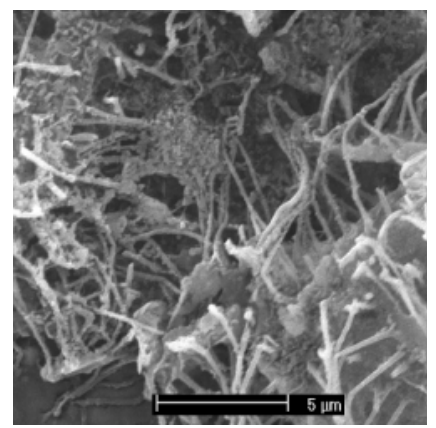

145

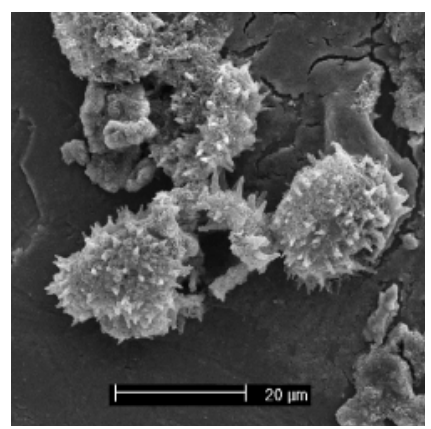

148

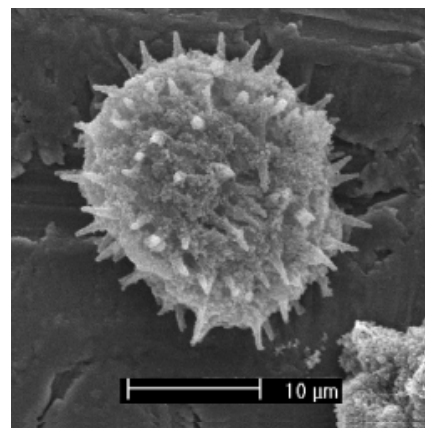

151

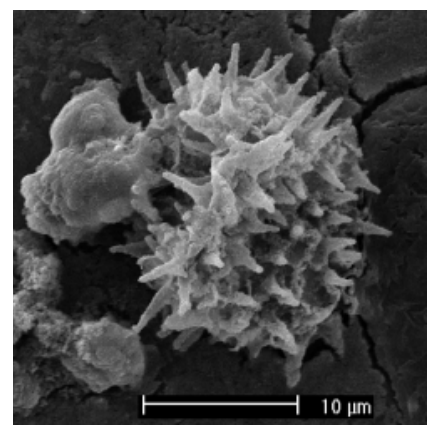

146

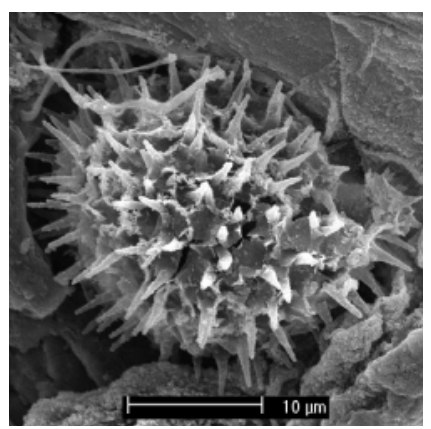

149

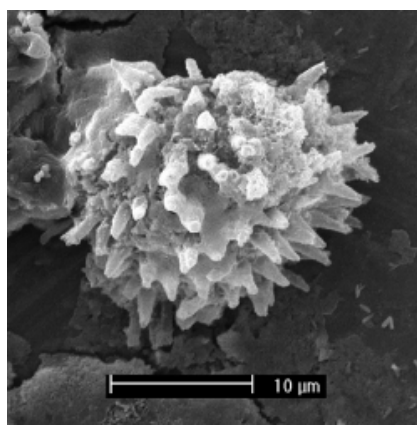

147

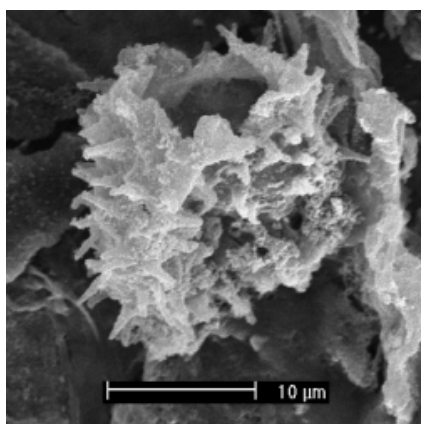

150 


\section{H. BRINKHUIS ET AL.}

\section{CHAPTER NOTES*}

N1. Stickley, C.E., Brinkhuis, H., Schellenberg, S.A., Sluijs, A., Fuller, M., Grauert, M., Röhl, U., Warnaar, J., and Williams, G.L., submitted. Timing and nature of the opening of the Tasmanian Gateway at the Eocene-Oligocene transition: ODP Site 1172. In Exon, N.F., Malone, M., and Kennett, J.P. (Eds.), Cenozoic Paleoceanography and Tectonics in the Expanding Tasmanian Seaway. Am. Geophys. Union, Geophys. Monogr.

N2. Huber, M., Brinkhuis, H., Stickley, C.E., Döös, K., Sluijs, A., Warnaar, J., Schellenberg, S.A., and Williams, G.L., submitted. Eocene circulation of the Southern Ocean: was Antarctica kept warm by subtropical waters? Science. 